\title{
Fontes primárias no ensino de física: considerações e exemplos de propostas ${ }^{+* 1}$
}

Giovanninni Leite de Freitas Batista ${ }^{2}$

Instituto Federal de Educação Ciência e Tecnologia do Rio Grande do Norte

Natal - RN

Juliana Mesquita Hidalgo Ferreira Drummond ${ }^{3}$

Daniel Brito de Freitas 4

Departamento de Física Teórica e Experimental - UFRN

Natal - RN

\section{Resumo}

Em contraste com a tendência positivista de outrora, fontes primárias não são mais consideradas como documentos oficiais que contém "a verdade sobre o passado". Atualmente, são compreendidas como artefatos culturalmente produzidos que refletem intencionalidades de personagens. São essenciais para o trabalho interpretativo realizado por historiadores $e$ historiadores da ciência. No contexto educacional, na disciplina escolar de História, os estudantes já costumam ser convidados a uma interpretação diacrônica de documentos históricos. De modo distinto, o uso desse tipo de material é ainda raro em iniciativas para a inserção da História e Filosofia da Ciência no ensino de Física. Adicionalmente, há lacunas quanto a refletir sobre o uso didático dessas fontes em aulas de Física numa perspectiva não ilustrativa, mas sim investigativa, a qual estaria em ressonância com pressupostos historiográficos da História da Ciência e

\footnotetext{
${ }^{+}$Primary sources in Physics teaching: considerations and examples of proposals

* Recebido: maio de 2015.

Aceito: setembro de 2015.

${ }^{1}$ O presente artigo foi desenvolvido como recorte de dissertação de mestrado em Ensino de Ciências Naturais (BATISTA, 2014). Os autores agradecem aos pareceristas do CBEF pelos comentários e sugestões que contribuíram para a versão final do trabalho que ora se apresenta.

2 E-mail: giovanninni@gmail.com

3 E-mail: juliana_hidalgo@yahoo.com

${ }^{4}$ E-mail: danielbrito@dfte.ufrn.br
} 
objetivos didáticos atualizados. Atividades investigativas, dialógicas, baseadas na interpretação diacrônica de documentos podem incentivar a curiosidade e a imaginação dos alunos acerca do processo de construção do conhecimento científico, evocando elementos usualmente ausentes em livros didáticos. O presente artigo reflete sobre tais questões e discute dois exemplos de possibilidades didáticas de uso de fontes primárias relacionadas à História do Vácuo e da Pressão Atmosférica.

Palavras-chave: Fontes primárias; Textos históricos; Natureza da Ciência.

\begin{abstract}
Primary sources are not anymore official documents which contain "the truth about the past". They are conceived as culturally produced artifacts which reflect the intentions of the groups that originated them. They are essential to the interpretive work accomplished by historians and historians of science. In the educational context, the use of primary sources from that perspective has been taking place in History teaching. Students are often invited to a diachronic interpretation of documents. In contrast, the use of this kind of material is still rare in initiatives for advancing History and Philosophy of Science in Physics teaching. In addition, there are gaps regarding reflections on the didactic use of these sources in Physics classes according to a non-illustrative perspective. An investigative approach would match to historiographical assumptions and updated educational goals. Investigative dialogical activities, based on diachronic interpretation of documents can encourage curiosity and imagination of the students about the construction of scientific knowledge, evoking elements usually absent in textbooks. The present work addresses these points and discusses didactic possibilities of using sources related to the History of Vacuum and Air Pressure.
\end{abstract}

Keywords: Primary sources; Historical texts; Nature of Science.

\title{
I. Introdução
}

Há décadas discute-se a respeito do papel da História e Filosofia da Ciência (HFC) no Ensino. No tocante ao aprendizado de conceitos científicos, nota-se significativa repercussão de implicações didáticas decorrentes de semelhanças entre concepções alternativas sustentadas 
por estudantes e conhecimentos científicos de épocas passadas. Propostas baseadas nessa perspectiva tomam como aporte a História da Ciência para lidar com dificuldades conceituais dos estudantes, buscando não subestimá-las. Percebendo que certos conceitos não podem ser introduzidos rapidamente, abordagens históricas sugerem contextos didáticos em que modificações conceituais são objetivadas (SALTIEL; VIENNOT, 1985; SILVEIRA, 1992; MATTHEWS, 1994; PEDUZZI, 2001; MARTINS, 2006; BUENO; PACCA, 2009).

Ademais, defende-se que a compreensão aprofundada dos conceitos científicos estaria relacionada ao entendimento dos problemas a que tais conhecimentos buscaram responder (MATTHEWS, 1994). Vem se reforçando a relevância de que o conhecimento científico seja contextualizado como tentativa de resolução de problemas em contraposição a uma visão aproblemática e ahistórica da ciência (GIL PÉREZ et al., 2001; PEDUZZI, 2001; MARTINS, 2006). Indica-se a importância de problematizar visões a-históricas, elitistas e individualistas da ciência, as quais costumam ser notadas no contexto educacional:

Muitas vezes insiste-se explicitamente em que o trabalho científico é um domínio re-
servado a minorias especialmente dotadas, transmitindo-se assim expectativas nega-
tivas à maioria dos alunos, [...]. Contribui-se, além do mais, para esse elitismo es-
condendo o significado dos conhecimentos por meio de apresentações exclusivamente
operativas. Não se faz um esforço para tornar a ciência acessível [...], nem para mos-
trar o seu carácter de construção humana, em que não faltam hesitações nem erros,
situações semelhantes às dos próprios alunos (GIL PÉREZ et al, 2001, p. 133).

A recorrência a episódios históricos vem sendo citada como possibilidade para a contextualização de discussões sobre a natureza do conhecimento científico (PEDUZZI, 2001; GIL PÉREZ et al., 2001; KOSMINSKY; GIORDAN, 2002; MARTINS, 2006; LEDERMAN, 2007; CLOUGH; OLSON, 2008; HOTTECKE; SILVA, 2011; SASSERON; BRICCIA; CARVALHO, 2013; BOAS et al., 2013).

O papel da HFC no Ensino é ressaltado quando se considera a insuficiência de apresentar em sala de aula apenas os produtos da ciência. Essa perspectiva de caráter limitado não daria conta de objetivos atuais da educação científica: "como o ensino de ciências, e, em particular, o de física pode contribuir para potencializar os alunos a produzirem respostas aos problemas de seu contexto sociocultural?" (GUERRA, 2014, p. 129). Despontam propostas de que conteúdos histórico-filosóficos estejam presentes no espaço escolar uma vez que:

[...] um dos principais objetivos do ensino de ciências na educação básica é proporcionar em sala de aula um espaço de reflexão que permita aos alunos conhecer limites e possibilidades do conhecimento científico, de forma a identificar como o mesmo foi justificado e fundamentado ao longo da história (GUERRA, 2014, p. 131).

Refletir sobre o processo de construção da ciência é uma perspectiva abraçada pela legislação educacional brasileira, que preconiza aliar produto e processo. A ciência deve ser compreendida como atividade humana socialmente construída. O conhecimento físico deve ser 
explicado como processo histórico, objeto de contínua transformação: “[a Física] percebida enquanto construção histórica [...] emerge da cultura e leva à compreensão de que modelos explicativos não são únicos nem finais" (BRASIL, 1999, p. 235).

Ao encontro do referido leque de possibilidades para a História e Filosofia da Ciência no Ensino, potencialidades didáticas das fontes primárias vêm sendo apontadas (BOSS; SOUZA FILHO; CALUZZI, 2009; BUENO; PACCA, 2009; BRICCIA; CARVALHO, 2011; LIBRARY OF CONGRESS, 2011; OLIVEIRA, 2011). Apesar disso, iniciativas que busquem de fato explorá-las no ensino de conteúdos de ciência e sobre a ciência ainda não são recorrentes no Brasil e no exterior (TEIXEIRA; GRECA; FREIRE JR., 2012).

Justificando esse panorama, nota-se que a inserção didática de fontes primárias da História da Ciência é cercada de desafios, como a localização de materiais adequados, a compreensão dos trechos originais e a elaboração de atividades pedagógicas interessantes. As dificuldades costumam ser reconhecidas mesmo por quem registra as potencialidades desses recursos (BOSS; SOUZA FILHO; CALUZI, 2011; BOSS, 2014).

Os desafios são grandes também no que diz respeito à formação docente para lidar com particularidades da inserção didática de fontes primárias (ver, por exemplo, FORATO, 2009). Pesquisa recente em oficina de formação docente na Universidade Federal do Rio Grande do Norte demonstra alguns resultados interessantes (OLIVEIRA, 2013). A oficina contemplou etapas de discussão sobre a transposição didática da HFC, inclusive no que diz respeito ao uso criterioso de fontes primárias (FORATO; MARTINS; PIETROCOLA, 2012b, p. 134135). Após as discussões, participantes se engajaram na elaboração de propostas didáticas a partir de texto de subsídio ao professor, o qual contemplava múltiplos e extensos trechos de fontes primárias. Percebeu-se, por um lado, o interesse dos participantes pelos referidos trechos e, por outro, a dificuldade de utilizá-los em propostas adequadas ao contexto educacional básico. Observou-se a composição de narrativas históricas contendo os mesmos trechos de fontes primárias disponibilizados para os professores, em igual proporção e volume, sem os devidos cuidados com recortes e elementos pudessem facilitar a compreensão pelos estudantes.

A referida pesquisa foi realizada por participante do grupo no qual se inserem autores do presente trabalho. Os resultados observados, em ressonância com referenciais que tratam da formação docente para a inserção didática da HFC (ver OLIVEIRA, 2013), motivaram a perspectiva de atuar na elaboração de propostas de transposição didática de fontes primárias, sendo tais propostas utilizadas como elementos para mediação de discussões com professores atuantes e em formação inicial. Como um desses desdobramentos situa-se, particularmente, a dissertação da qual o presente artigo advém como recorte (BATISTA, 2014).

Os elementos em destaque nesse artigo foram discutidos em curso de formação docente, elaborado e implementado na UFRN, em 2013, como um dos produtos educacionais da referida dissertação. As seções apresentadas a seguir sugerem a necessidade de se levar em conta, para fins didáticos, perspectivas historiográficas atualizadas sobre o que seriam "fontes primárias”. Aplica-se ao caso específico da inserção didática de fontes primárias a consideração 
geral de que "conhecer alguns pressupostos básicos da historiografia pode auxiliar nos usos da HFC no ensino de ciência" (FORATO; MARTINS; PIETROCOLA, 2011, p. 36). Defende-se aqui que essa compreensão traz desdobramentos de natureza metodológica para eventuais propostas que busquem utilizar fontes primárias como recursos pedagógicos. Nesse sentido, realizam-se considerações que pretendem contribuir para a reflexão a respeito da inserção desses recursos no contexto educacional.

Particularmente, são trazidos à tona dois materiais elaborados, os quais serviram para a mediação de discussões no curso de formação realizado. Esses materiais se relacionam à História do Vácuo e da Pressão Atmosférica e podem ser utilizados por docentes em salas de aula da educação básica.

Por motivos de restrição de espaço, foram escolhidos somente dois componentes de uma Unidade Didática, a qual pode ser consultada em sua totalidade (BATISTA, 2014). Justifica-se a pertinência da referida seleção para efeitos das reflexões aqui focalizadas. Discutemse possibilidades de utilização didática de documentos históricos segundo uma perspectiva investigativa, em concordância com pressupostos historiográficos coetâneos e argumentação atual sobre a HFC no Ensino.

Para a elaboração desses materiais, buscou-se contemplar uma das possibilidades de utilização da abordagem histórica no ensino. A temática natureza do conhecimento científico transparece entre os objetivos didáticos focalizados ${ }^{5}$. Considera-se que os materiais podem contribuir com elementos importantes também para a compreensão dos conceitos científicos, uma vez que permitem perceber a que problemas buscaram responder (MATTHEWS, 1994). Sugere-se que esses objetivos sejam contemplados mediante uma participação ativa do estudante na interpretação das fontes primárias, em atividades que os potencializem como produtores de conhecimento (GUERRA, 2014).

\section{Sobre o uso didático de fontes primárias}

\section{II.1 Potencialidades e dificuldades}

Considerando os argumentos favoráveis à inserção da HFC no Ensino, diversas potencialidades das fontes primárias vêm sendo apontadas. Segundo Briccia e Carvalho (2011), a utilização de textos históricos em sala de aula permite problematizar visões inadequadas da ciência, como individualista e algorítmica, e, por outro lado, é significativa no tocante à percepção da ciência como produção humana. Boss, Souza Filho e Caluzzi (2009) relatam bons resultados no ensino superior com o uso de textos originais para a aprendizagem de conceitos físicos. Oliveira (2011) apresenta resultados satisfatórios em pesquisa empírica sobre o uso de

\footnotetext{
${ }^{5}$ Foram realizados recortes em relação às possibilidades de inserção didática da HFC. Optou-se, nesse caso, por não adotar a perspectiva de contemplar as relações entre História da Ciência e concepções alternativas. Essa outra possibilidade vem sendo adotada em trabalho em andamento, conforme nota explicativa inserida mais adiante.
} 
documentos históricos para o ensino de conceitos em curso de formação de professores de ciência.

O projeto norte-americano Teaching with Primary Sources é uma iniciativa inspiradora no sentido de identificar e buscar alternativas para explorar potencialidades das fontes primárias. Algumas dessas potencialidades seriam: conectar conceitos a seres humanos, pesquisadores; aprender sobre o caminho frequentemente difícil da investigação científica; perceber diferentes metodologias científicas; notar que pesquisadores cometem erros e que esses não são derrotas, mas sim desafios; incentivar a imaginação e a curiosidade dos alunos (LIBRARY OF CONGRESS, 2011).

Apesar das sugeridas potencialidades, iniciativas de explorá-las ainda são incipientes. Pesquisa recente do tipo "estado da arte" identificou em revistas brasileiras da área de ensino de Física raros trabalhos que utilizam esse tipo de recurso em intervenções didáticas (TEIXEIRA; GRECA; FREIRE JR, 2012). Resultados semelhantes figuram em mapeamentos de trabalhos apresentados em eventos (QUEIRÓS; BATISTETI; JUSTILA, 2009; BEZERRA, 2014).

Os desafios que cercam a inserção de fontes primárias da História da Ciência em sala de aula podem colaborar para a compreensão desse contexto. Não é trivial localizá-las e, menos trivial ainda é encontrá-las em vernáculo, sendo essa uma necessidade importante para o seu uso didático em nosso país (BOSS; SOUZA FILHO; CALUZI, 2011; BOSS, 2014). Ademais, o processo de tradução de uma fonte primária é complexo, exige conhecimento profundo do idioma original. Deve levar em conta o tratamento diacrônico, a reflexão sobre o contexto histórico e científico do período. Requer respeitar a terminologia original. "Modernizar" os conceitos ou a terminologia científica significa fazer uma história anacrônica, "que não compreende o passado" (VIDEIRA, 2007, p. 141).

Mesmo o acesso a uma fonte primária adequadamente traduzida para o vernáculo não garante a possibilidade de sua inserção em sala de aula. Interpretar documentos históricos não representa uma atividade simples, mesmo para o próprio historiador da ciência:

[...] o tratamento de fontes primárias exige, além de um conhecimento técnico específico, um amplo domínio do contexto de época e do pensamento do autor [...]. E não se espera que professores e estudantes de Física desenvolvam essa competência no mesmo nível dos historiadores (DION; LOURES, 2013, p. 200).

Boa parte das fontes primárias apresenta inerente complexidade, o que compromete sua leitura e entendimento pelos estudantes (BOSS; SOUZA FILHO; CALUZI, 2011). No caso das fontes primárias, há algumas especificidades intrínsecas a esses recursos. É preciso atentar para a escolha adequada do que será levado à sala de aula: "é necessário selecionar um trecho inteligível ao aluno, despertar nele algum interesse, e não ser demasiado longo do ponto de vista do nível de escolaridade focado" (FORATO; MARTINS; PIETROCOLA, 2012b, p. 135). 
O uso dessas fontes requer o acompanhamento de professor que conheça pelo menos minimamente o período histórico analisado, possibilitando uma interpretação diacrônica daquele período (FORATO, 2009, p. 105). Levar fontes primárias ao ensino de Física requer do professor a consulta a fontes secundárias que o auxiliem, minimizando interpretações equivocadas. Ao optar pela sua utilização, o professor deve ter certo conhecimento das circunstâncias contextuais, bem como certo conhecimento sobre o período histórico elencado.

No contexto educacional é importante refletir sobre "quando, quanto e como utilizar trechos de fontes primárias" (FORATO; MARTINS; PIETROCOLA, 2012b, p. 134). Adicionalmente, existe o desafio de preparar atividades pedagógicas interessantes utilizando tais recursos. Às questões particulares relacionadas ao uso de fontes primárias agregam-se obstáculos gerais que costumam ser relatados a respeito da inserção da HFC no contexto educacional, como a adequação do nível de aprofundamento dos aspectos históricos e epistemológicos (FORATO, 2009; HÖTTECKE; SILVA, 2010).

Desponta a necessidade de explorar as potencialidades desses recursos, embora os desafios sejam grandes. Mas, valeria mesmo à pena enfrentá-los?

A seção seguinte ensaia um "sim" como resposta a esse questionamento. A utilização de fontes primárias no ensino de Física segundo uma concepção investigativa, alinhada a pressupostos historiográficos atualizados, pode vir ao encontro da perspectiva de "potencializar os alunos como produtores de conhecimento" (GUERRA, 2014, p. 129).

\section{II.2 Ampliando reflexões}

O termo historiografia pode ser definido como "um discurso crítico, que procura mostrar, o mais claramente possível, as bases epistemológicas, históricas, políticas e axiológicas sobre as quais os discursos históricos são construídos" (VIDEIRA, 2007, p. 122). Observa-se ainda a seguinte acepção para historiografia: "produto primário da atividade dos historiadores. [...] reflete sobre os acontecimentos históricos, mas agrega-lhe um caráter discursivo novo. [...] não é uma mera descrição da realidade histórica" (MARTINS, 2005, p. 115).

A historiografia passou por profundas transformações no século passado em decorrência de revisões de pressupostos metodológicos e teóricos. Olhares foram redirecionados em decorrência, por exemplo, de uma reflexão crítica acerca do anacronismo e de comparações que implicariam juízos de valor. No que concerne ao ofício de historiadores e historiadores da ciência, ocorreram modificações agudas no que se entende por "fontes primárias", com repercussões significativas para a forma de abordá-las. Houve certo distanciamento em relação à concepção positivista de outrora. Atualmente, fontes primárias não são mais "relatoras da verdade sobre o passado". Lê-las não nos permite saber como realmente as coisas ocorreram. Em contraposição a essa perspectiva, são concebidas como artefatos culturalmente produzidos, que refletem as intenções dos grupos que as originaram. São essenciais para o trabalho interpretativo realizado por historiadores e historiadores da ciência. Esses profissionais procuram compreender possíveis significados de tais evidências, levando em conta as visões de mundo do 
passado (MARTINS, 1993; ALFONSO-GOLDFARB, 1994; MARTINS, 2001; CAIMI, 2008; XAVIER, 2010).

Tendo em vista tais reformulações, é pertinente refletir sobre eventuais desdobramentos para a utilização didática de fontes primárias na disciplina escolar de História e nas disciplinas científicas, particularmente na Física, no tocante à inserção didática da HFC.

De acordo com a compreensão de que o conhecimento histórico não é composto por verdades últimas, mas sim por "verdades provisórias", que refletem o olhar do historiador, o ensino da disciplina escolar de História passou por transformações significativas (CAIMI, 2008; XAVIER, 2010).

Atualmente, as fontes históricas são habituais frequentadoras das aulas de História, onde não mais exercem o papel de meras ilustrações de conteúdos. Esse tipo de material desempenha uma função pedagógica importante. Pretende-se que os estudantes possam fazer parte do processo de construção do conhecimento histórico. Em atividades que envolvem a mediação do professor, os estudantes exercem papel ativo na leitura e interpretação diacrônica de fontes primárias. Nota-se a sintonia entre pressupostos historiográficos atuais e a utilização didática desses recursos (XAVIER, 2010).

De forma análoga ao que vem ocorrendo com a disciplina escolar de História, sugerese, aqui, que iniciativas para o ensino de Física tenham como ponto de partida a reflexão sobre o entendimento do que são as fontes primárias de acordo com pressupostos historiográficos atualizados. Pode-se, assim, buscar inspiração nas transformações recentes na disciplina escolar de História, na qual a utilização de fontes primárias atende ao referido critério. Mas, por que isso deveria ocorrer?

Seria adequado atender ao que coetaneamente se concebe como "fontes primárias" na área acadêmica de História da Ciência, uma vez que pensá-las em sua inserção didática demanda atenção às visões sustentadas pela historiografia da História da Ciência nas últimas décadas.

Em relação a recursos didáticos para a prática docente, Schmiedecke e Porto (2013) apontam a importância de que critérios historiográficos contemporâneos orientem escolhas mais críticas e efetivas. Esse aspecto já vem sendo enfatizado em reflexões teóricas sobre a HFC no Ensino no tocante à elaboração de narrativas históricas para uso didático. Segundo Videira (2007, p. 123), "uma narrativa histórica será melhor, quanto mais consciente for o seu autor dos pressupostos historiográficos empregados para elaborá-la”. Para Forato, Martins e Pietrocola (2012b, p. 126): “A elaboração de narrativas históricas e os aspectos epistemológicos que elas transmitem podem ser avaliados e orientados pela historiografia atual da História da Ciência" $"$.

\footnotetext{
${ }^{6}$ Apesar de reconhecida relevância para o contexto educacional, essas considerações pouco têm se materializado efetivamente em materiais didáticos e na prática educacional (PAGLIARINI; SILVA, 2006; BATISTA; MOHR; FERRARI, 2007; PENA; TEIXEIRA, 2013).
} 
Dessa forma, pressupostos historiográficos deveriam orientar também a inserção de fontes primárias em salas de aula. No âmbito da HFC no Ensino as fontes primárias não deveriam ser utilizadas em aula como meras ilustrações para os conteúdos, para mostrar como os “fatos da ciência realmente ocorreram". Não seria adequado utilizar fontes históricas para apresentar aos estudantes a verdade sobre como um experimento ocorreu ou de fato como uma teoria surgiu.

É importante refletir, no entanto, sobre se adotar essa perspectiva no tocante à utilização didática das fontes primárias na disciplina de Física adviria de um mero preciosismo histórico, desnecessário, que não traria repercussões pertinentes para o próprio ensino de Física.

Refletindo sobre essa questão, defende-se aqui que a utilização de fontes primárias no ensino de Física deve ser fomentada de acordo com uma perspectiva historiográfica atualizada, justamente tendo em vista objetivos atuais da educação básica ${ }^{7}$. Delineia-se "adotar uma postura de não tratar seu aluno como recipiente de verdades" (OLIVEIRA, 2011). Considerando o propósito de "preparar indivíduos para que possam atuar de forma ativa na sociedade" (GUERRA, 2014, p. 129), buscam-se metodologias que se aproximem de ações investigativas (LARANJEIRAS, 2014).

Assim, sugere-se a possibilidade de que os estudantes se engajem na leitura e reflexão diacrônica sobre fontes selecionadas da História da Ciência tendo em vista construir interpretações sobre o processo de construção da ciência. Como pontua Oliveira (2011, p. 80), "é importante permitir ao leitor inscrever-se em uma disputa de interpretações".

Nesse tipo de proposta, os estudantes podem desempenhar um papel ativo ao serem instigados: a investigar possíveis intenções de personagens e seus registros; a elaborar e discutir hipóteses a respeito do processo de construção de conhecimentos científicos; a imaginar aparatos e experimentos descritos nas fontes primárias; a analisar de forma diacrônica questões metodológicas, construindo percepções acerca de diferenças e semelhanças entre pesquisas de épocas distintas; a notar possíveis temas de relevância para a ciência em distintos momentos; a interpretar reações humanas de pesquisadores, como alegria, hesitação e dúvida, e a investigar sobre relações de pesquisadores na comunidade científica. Atividades dialógicas de interpretação, sob a mediação do professor, podem colaborar para que os alunos construam imagens da ciência como empreendimento coletivo humano.

A inserção didática de fontes primárias segundo uma perspectiva investigativa, que corresponda a objetivos educacionais coetâneos, pode advir justamente da recomendação de que pressupostos historiográficos atualizados orientem a utilização desses recursos. Essa concepção se contrapõe à compreensão das fontes primárias como reveladoras da verdade, mera ilustração para conteúdos que se deseja dogmaticamente transmitir.

\footnotetext{
${ }^{7} \mathrm{O}$ mesmo se pode dizer a respeito do ensino de outras disciplinas científicas.
} 


\section{Exemplos de propostas para a inserção didática de fontes primárias}

Os documentos históricos citados nas seções subsequentes foram traduzidos a partir do Source book in Physics, obra de referência organizada por William Magie (1969, p. 70-73). Essa coletânea de textos históricos significativos da Física ainda é pouco explorada em propostas de intervenções didáticas no Brasil ${ }^{8}$.

Face à perspectiva assinalada, são discutidas propostas distintas de utilização didática de duas fontes primárias: uma carta de 1644, na qual Evangelista Torricelli escreve sobre sua pesquisa, e uma correspondência de 1648 entre Blaise Pascal e seu cunhado Florin Périer, na qual este descreve a realização de experimento no Puy-de-Dôme. No primeiro caso, sugere-se a utilização de trechos da carta original entremeados por explicações que visam colaborar para a cognoscibilidade dos mesmos. No segundo caso, sugere-se o uso direto da própria correspondência em sala de aula.

Tendo em vista a elaboração de material para a educação básica ${ }^{9}$, escolheu-se a História do Vácuo devido ao rico potencial didático, ainda pouco explorado no ensino de Física. Para a seleção dos textos históricos, foi relevante uma percepção mais ampla do significado desses episódios para a própria História da Ciência, bem como a compreensão dos problemas e contextos envolvidos. Segundo Dion e Loures (2013, p. 201): “É somente a partir daí que se pode adquirir um critério de escolha, de forma a fazer um recorte [...] que atenda aos objetivos previamente definidos".

Nesse sentido, fundamentalmente, a seleção levou em conta a inteligibilidade dos escritos, considerando o Ensino Médio como nível educacional visado, e, no tocante aos objetivos, a potencialidade para discutir sobre a natureza do conhecimento científico e trazer à tona problemas a que os conhecimentos científicos buscaram responder. Tomou-se como recorte, portanto, uma das possibilidades de utilização da abordagem histórica no ensino ${ }^{10}$.

\footnotetext{
${ }^{8}$ Pode ser citada, como exemplo, a iniciativa relatada por Sasseron, Briccia e Carvalho (2013).

${ }^{9}$ Encontra-se em andamento pesquisa empírica que investiga a utilização desse material no contexto da educação básica. É relevante lembrar que, no contexto da dissertação da qual o presente artigo advém como recorte, o material foi utilizado como elemento para mediar discussões em oficina de formação docente sobre possibilidades de inserção didática de fontes primárias. O relato fundamentado dessa aplicação foge ao escopo do presente trabalho, podendo ser consultado (BATISTA, 2014).

${ }^{10}$ Outra possibilidade teria como fundamentação as relações entre História da Ciência e concepções alternativas visando ensinar conceitos científicos. A elaboração de intervenção didática de cunho histórico-filosófico, a qual tem como ponto de partida concepções alternativas a respeito do vácuo e da pressão atmosférica (SOLAZ-PORTOLEZ, 2008), vem sendo realizada em dissertação em andamento no grupo de estudos do qual advém o presente trabalho. A intervenção a ser implementada na educação básica insere os estudantes em tentativa inicial de construção de explicações para fenômenos do cotidiano, como o funcionamento de seringas, bebedouros de pássaros e lacres de potes de requeijão. Considerando iniciativas semelhantes desenvolvidas sobre outros conceitos (por exemplo, BUENO; PACCA, 2009), propõe que os alunos se engajem em processo "investigativo" que permita: a percepção de semelhanças entre suas próprias explicações iniciais e concepções expressadas por pensadores do passado em documentos históricos; a compreensão do processo histórico de construção do pressuposto "pressão atmosférica"; a percepção da inexistência ou da fragilidade desse fator em suas explicações iniciais e a possibilidade de reconsiderá-las à luz desse elemento. Sob um prisma diferente do explicitado no presente artigo, a intervenção aborda as fontes primárias do ponto de vista conceitual, discutindo significados físicos.
} 
Visou-se à possibilidade de contemplar lacunas usualmente notadas no contexto escolar básico, sugerindo material complementar como recurso didático. Ao introduzirem o conceito de pressão atmosférica, livros didáticos costumam relacioná-lo ao experimento realizado por Torricelli no século XVII. O experimento transparece como uma tentativa isolada e "certeira" de medir a pressão atmosférica. Não costuma haver referência à importante controvérsia científica na qual o experimento se inseria. Não são mencionadas as diferentes possibilidades de interpretação para a sustentação da coluna de mercúrio na época, as dificuldades enfrentadas pelo pesquisador e a continuidade dos estudos por outros autores. Sobre Pascal, também pouco aparece além da associação à unidade de medida de pressão ${ }^{11}$.

Os escritos originais retratam, ao contrário do que costuma aparecer em livros didáticos, que Torricelli não estava plenamente satisfeito com suas conclusões e sustentava pensamentos dissidentes para a sua época. Também a ausência de experimentos que inspiraram Torricelli, a rara menção ao experimento do Puy-de-Dôme e a omissão da indissociável discussão sobre o vazio como ponto de partida para tais pesquisas, exemplificam o foco usual dos livros didáticos: conceitos prontos, finalizados, "produtos da ciência" (PAGLIARINI, 2007; BATISTA; MOHR; FERRARI, 2007).

Considerando tais lacunas, a inserção didática das propostas apresentadas nas seções subsequentes poderia ocorrer a partir de certos questionamentos em sala de aula: Seria o foco de Torricelli somente medir a pressão atmosférica? A figura no nosso livro ${ }^{12}$ mostra um espaço "vazio" no tubo do experimento de Torricelli. Será que estava realmente vazio na visão do Torricelli? Existiam opiniões diferentes sobre isso? Seria mesmo possível concluir que a sustentação do mercúrio se devia a algo externo? Ao observar o experimento era possível "ver" a pressão atmosférica atuando? Será que Torricelli teve alguma dificuldade? Ele chegou mesmo a uma conclusão final? O que houve depois do experimento de Torricelli?

A problematização sugerida extrapola o conteúdo usualmente observado em livros didáticos. Remete a uma compreensão mais aprofundada dos conceitos por meio da discussão do desenvolvimento histórico dos mesmos. Conforme vem assinalando a literatura, esses materiais são insuficientes no que se refere à temática HFC, deixando de lado esse tipo de discussão. Desse modo, o professor teria que recorrer a propostas complementares que explorem a inserção dessas questões em sala de aula (BATISTA; MOHR; FERRARI, 2007).

\footnotetext{
${ }^{11}$ Sugere-se a consulta da dissertação para aprofundamento desses elementos que no presente artigo aparecem de modo superficial. Julgou-se conveniente delinear aqui tais críticas uma vez que se propõe o uso das fontes primárias como material complementar. Na dissertação, que se intitula "Fontes Primárias da História do Vácuo e da Pressão Atmosférica na sala de aula: cartas e jornais históricos em articulação com o livro texto do Ensino Médio" (BATISTA, 2014), referências a essas fragilidades são aprofundadas com a discussão de exemplares (GASPAR, 2001; FERRARO; SOARES, 2003; BONJORNO et al, 2003; DOCA; BISCUILA; BÔAS, 2007; GASPAR, 2011). Pode-se, então, compreender o significado e a amplitude das lacunas aqui citadas de passagem. Nesse sentido, é válido esclarecer que a Unidade Didática integral é composta por uma sequência de oito momentos, os quais se iniciam e terminam em livros didáticos. Busca-se, ao final, a resolução de questões usualmente encontradas em listas de exercícios nesses materiais, trazendo à tona a possibilidade de articulação dos seus enunciados a episódios da História da Ciência.

${ }^{12}$ Esse registro é frequente em desenhos sobre o experimento de Torricelli nos livros didáticos.
} 
Esse pode ser um ponto de partida para a utilização didática das fontes primárias. Por outro lado, para que o professor possa utilizar e adaptar propostas não basta que as conheça. Entre outros fatores, a compreensão aprofundada do desenvolvimento histórico desses conhecimentos é fundamental. Para o caso focalizado no presente artigo são recomendados adiante textos de apoio dos quais o professor pode se beneficiar.

\section{1 Possibilidade de utilização didática da carta de Torricelli}

\section{III.1.1 Proposta de entrevista fictícia}

Em junho de 1644, Evangelista Torricelli descreveu suas pesquisas em carta ao estudioso Michelangelo Ricci. A tradução dessa carta, realizada pelos autores do presente trabalho, levou em conta o tratamento diacrônico dos escritos originais, o que demandou reflexões sobre o contexto histórico e científico, a visão de ciência e a nomenclatura científica usual do período (tradução completa no Apêndice 1).

Entretanto, mesmo em vernáculo, as características da carta em termos de conteúdo e formulação discursiva podem constituir um empecilho a utilizá-la na forma integral no contexto educacional básico. Uma possibilidade de lidar com esses obstáculos é a utilização de recortes da fonte primária de modo que "tais trechos venham entremeados por explicações e esclarecimentos para auxiliar sua interpretação" (FORATO, 2009, p. 105).

Adotou-se essa perspectiva na composição de uma entrevista fictícia com Evangelista Torricelli. A entrevista compõe a quinta edição do Jornal Histórico - A Tribuna da Ciência: Muito barulho pelo nada (ver Apêndice 2).

Elaborado para aplicação no Ensino Médio, o jornal é ambientado nos dias atuais. Traz conteúdos de História da Ciência, particularmente, episódios da História do Vácuo e da Pressão Atmosférica. É composto por cinco edições. A Edição I abrange as discussões na Antiguidade envolvendo Aristóteles, eleatas e atomistas quanto à existência do vazio. Em meio aos argumentos apresentados, encontram-se elementos das diferentes interpretações das escolas filosóficas a respeito de fenômenos como movimento e luz. A Edição II remete a discussões da Era Cristã e Idade Média. Evidencia a forte negação do vazio, com argumentos que retomam a influência aristotélica na interpretação de elementos do cotidiano (como o funcionamento de um sifão e de um canudo para sorver líquidos), bem como articula diversos experimentos imaginários. A controvérsia se faz presente na medida em que alguns pensadores sustentam a possibilidade do vazio. As Edições III e IV trazem aspectos dessas discussões na Revolução Científica, quando o horror ao vazio é ainda uma tradição marcante. No entanto, na época, a defesa do vazio ganha evidência com a retomada de argumentos atomistas e novos argumentos surgem em meio à visão de que o ar possui peso e exerce pressão. As edições ressaltam a forte cooperação, trocas de informações entre os pensadores e propostas de vários experimentos para discutir sobre o vazio. Esses seriam antecedentes e inspiração para o experimento realizado por Evangelista Torricelli. A visão de que o ar possui peso e exerce pressão se dissemina, mas a 
controvérsia sobre o vazio não é encerrada. A Edição V, como citamos, traz a entrevista fictícia com Torricelli 13 .

Considerou-se a relevância de tais episódios para a contextualização da temática Natureza da Ciência (NdC): “[...] em qualquer nível, exemplos da história da ciência são úteis para gerar discussões sobre $\mathrm{NdC}$ e compreender sua natureza contextual" (CLOUGH; OLSON, 2008, p. 144). Objetivou-se contemplar elementos relacionados à natureza do conhecimento científico por meio da discussão dos episódios históricos, em particular, trazidos à tona com o auxílio de fontes primárias.

Em relação aos recortes realizados, é importante frisar que, nas narrativas, o contexto científico no tocante às discussões sobre o vazio é destacado e sua influência é explorada, ao passo que aspectos econômicos, sociais e políticos dos períodos citados não. As narrativas não apoiam a visão de pesquisador neutro, alheio a esses aspectos. Por outro lado, contemplá-los não foi prioridade na elaboração das mesmas. O recorte deliberado pode abrir caminho para eventuais intervenções interdisciplinares (com as disciplinas de História e Geografia, por exemplo), nas quais os estudantes sejam estimulados a pesquisar sobre tais aspectos.

O jornal é constituído por recortes de escritos originais dos personagens participantes dos episódios históricos em questão - selecionados a partir de critérios como relevância e inteligibilidade. A esses trechos, em formatação diferenciada, e, portanto, visualmente distinguíveis pelo leitor, agregam-se trechos elaborados pelos autores do jornal com a intenção de favorecer a cognoscibilidade das passagens extraídas dos documentos originais. As capas das edições trazem esse esclarecimento.

Na composição da "Entrevista com Torricelli" foram utilizados excertos traduzidos da carta escrita pelo próprio pesquisador (Apêndice 1). Como a capa da Edição V esclarece, trata-se de um encontro imaginado entre Torricelli e um jornalista interessado em aspectos do seu trabalho (Apêndice 2). As questões propostas pelo personagem-jornalista foram elaboradas em linguagem coloquial, acessível, a fim de facilitar a interlocução com os estudantes-leitores. Procuram tornar inteligíveis os trechos originais, os quais na entrevista fazem o papel de respostas.

A comparação entre a carta e a entrevista, apresentadas, respectivamente nos Apêndices 1 e 2, permite acompanhar a proposta desenvolvida. Trata-se, portanto, da composição de uma espécie de narrativa centralizada nos recortes da fonte primária.

De acordo com perspectivas historiográficas atuais, o documento usado como base para a entrevista reflete as intencionalidades de Evangelista Torricelli. Reflete a maneira como Torricelli escolheu representar situações que vivenciou, relações e elementos de suas pesquisas, em circunstância particular de diálogo com interlocutor interessado. Torricelli comentou sobre

\footnotetext{
${ }^{13}$ As cinco edições do jornal, bem como uma proposta de utilização completa do material em Unidade Didática, podem ser consultadas em BATISTA, 2014.
} 
problemas de seu interesse, citou pressupostos que fundamentaram suas conclusões e deixou transparecer dúvidas e dificuldades.

Considerando tal entendimento, buscou-se na composição da entrevista permitir certa autonomia do estudante-leitor quanto à possibilidade de interpretar visões e registros de Torricelli. É importante destacar, no entanto, que a utilização didática da entrevista em atividade de caráter investigativo requer a mediação do professor como aspecto essencial, sinalizado por trabalhos que refletem sobre o potencial didático de narrativas (RIBEIRO; MARTINS, 2007). $\mathrm{O}$ material proposto apresenta potencialidades de uso para trazer à tona reflexões sobre a natureza do trabalho científico. Por outro lado, é ingênuo considerar que a simples composição de um conjunto de perguntas e respostas leva à reflexão.

Podem-se estimular questionamentos sobre a imagem que Torricelli procurou transmitir sobre suas pesquisas, o que tencionou revelar, como retratou controvérsias da ciência, como registrou suas ideias e de outros autores, se expressou abertamente ou deixou transparecer certezas, dúvidas, metas, argumentos e expectativas. Podem-se instigar perguntas sobre a integração do personagem na comunidade científica e o modo como ele relatou essa relação.

Uma proposta didática completa de utilização das cinco edições do jornal permitiria aprofundamento recomendável a respeito dos antecedentes do experimento de Torricelli, proporcionando contextualização ${ }^{14}$ consistente quanto a esse experimento. Uma sugestão mais abrangente nesse sentido é apresentada na dissertação da qual o presente artigo provém como recorte (BATISTA, 2014). Pretendeu-se, no entanto, que a inserção didática do jornal pudesse ser flexível, considerando que o contexto educacional demanda tal flexibilização: "Os professores precisam se sentir beneficiados com os novos materiais, [...], os materiais devem ser elaborados de modo flexível de forma a permitir que os professores os adaptem às suas condições atuais e locais" (HÖTTECKE; SILVA, 2010, p. 17).

Assim, de acordo com objetivos didáticos previamente delimitados, é possível utilizar todas as edições ou particularmente algumas delas. A seção seguinte traz comentários a respeito das potencialidades de utilização didática da entrevista, considerando uma situação na qual não necessariamente o professor pretenda (ou possa) utilizar as demais edições do jornal. Nesse caso, certa compreensão moderada a respeito dos antecedentes do experimento de Torricelli pode ser atingida por meio de referências do próprio Torricelli, na entrevista, ao contexto de sua pesquisa. Essa compreensão pode ser ampliada de acordo com a atuação do professor, como será explicitado.

\section{III.1. 2 Discutindo em detalhes as potencialidades da entrevista}

A investigação pode estimular a imaginação dos estudantes, dirigindo a atenção a aspectos relacionados ao "processo da ciência" e ao seu inerente caráter humano. Pode permitir,

\footnotetext{
14 Considera-se o termo "contextualização" de acordo com as limitações já assinaladas.
} 
assim, o contato com elementos que extrapolam os "produtos da ciência" ${ }^{15}$ usualmente trazidos nos livros didáticos. Possibilita, ainda, de acordo com a mediação realizada, a percepção do caráter interpretativo da História da Ciência.

Apresentam-se a seguir comentários que buscam contextualizar cada conjunto pergunta-resposta, isto é, cada bloco que compõe a entrevista (Apêndice 2). Esses comentários visam colaborar para que o professor perceba potencialidades da entrevista ao compreender a tônica das colocações de Torricelli. A interpretação da entrevista em aula pode sugerir respostas para questões surgidas em problematização anterior.

\section{Primeiro bloco}

Jornalista: Então... Existe o vazio ou não?

Torricelli: Fizemos muitos recipientes de vidro como aqueles mostrados em A e B com tubos de dois cúbitos de comprimento. Estes foram preenchidos com mercúrio, suas extremidades fechadas com o dedo, e foram, então, invertidos em um recipiente Conde havia mercúrio; vimos que um espaço vazio foi formado e que nada aconteceu no tubo onde esse espaço foi formado; o tubo entre A e D permaneceu sempre cheio até a altura de um cúbito e um quarto e uma polegada. Para mostrar que o tubo estava completamente vazio, enchemos a bacia com água pura até $D$ e então, erguendo o tubo pouco a pouco, vimos que, quando a abertura do tubo alcançou a água, o mercúrio caiu do tubo e a água subiu com grande violência até a marca $E^{16}$.

A primeira pergunta da "entrevista" foi elaborada a fim de colaborar para que se compreenda que Evangelista Torricelli dedicava-se a discutir sobre a existência do vazio. O referido experimento era relatado por ele como evidência empírica favorável à existência do vazio.

$\mathrm{O}$ experimento consistia em dois tubos, cheios de mercúrio, que foram invertidos em um recipiente onde também havia mercúrio. Nesse caso, Torricelli interpretou que o mercúrio descia até certa altura no tubo de vidro, deixando acima um espaço vazio. O pesquisador, então, discutiu e defendeu a possibilidade de existência do vazio recorrendo a um argumento empírico. Essa atitude indica que a interpretação não era a única, isto é, havia quem defendesse que o espaço acima do mercúrio não estava vazio.

No mesmo recorte, Torricelli discorreu sobre o processo de colocar água sobre o mercúrio na bacia e elevar o tubo lentamente. Quando a parte inferior do tubo (aberta) atingiu a superfície da água, este líquido adentrou o tubo, preenchendo-o completamente. Devido à diferença de densidade entre os dois líquidos, o mercúrio desceu para a bacia. Argumentando a favor da interpretação de que o vazio podia ocorrer na natureza, Torricelli considerou que o fato

\footnotetext{
${ }^{15} \mathrm{O}$ ensino das disciplinas científicas reforça uma concepção a-problemática e a-histórica da ciência ao transmitir: “[...] os conhecimentos já elaborados, sem mostrar os problemas que lhe deram origem, qual foi a sua evolução, as dificuldades encontradas etc. [...]” (GIL PÉREZ et al., 2001, p. 131).

${ }^{16}$ O sublinhado indica trecho extraído do documento original.
} 
de a água ter preenchido toda a parte superior do tubo indicava que esta parte antes estava vazia. Pode-se observar, assim, que o foco do pensador era discutir acerca do vazio. Ao menos nesse experimento, ele não expressou qualquer intenção de medir a pressão atmosférica.

Nos livros didáticos não se costuma observar menção à controvérsia sobre o vazio. $\mathrm{O}$ experimento de Torricelli aparece associado a esse único pensador, de forma repentina, descontextualizado, desconectado desse problema importante sobre o qual a comunidade científica da época se debruçava. Transparece a impressão de que seria um experimento exclusivamente dirigido a medir a pressão atmosférica.

\section{Segundo bloco}

Jornalista: Então o senhor está aceitando que o vácuo existe? Mas esse assunto divide opiniões entre os pesquisadores, não é verdade?

Torricelli: "Muitos disseram que o vácuo não existe, outros que de fato existe apesar da repugnância da natureza e com dificuldade; eu não conheço alguém que tenha dito que exista sem dificuldade e sem uma resistência da natureza. Aceito a existência do vácuo, mas ele ocorre com alguma resistência na natureza".

O trecho escrito por Torricelli nos remete a um problema que envolvia a comunidade científica na época. Como o pensador ressalta, existiam diferentes posicionamentos na discussão acerca da existência do vazio. Esse aspecto é enfatizado, então, na pergunta elaborada para compor a suposta entrevista.

Alguns aspectos e expressões que aparecem nessa fala do pensador não são esclarecidos nessa entrevista. Exemplo disso é a expressão "Repugnância da natureza" utilizada por Evangelista Torricelli em referência ao Horror ao Vácuo. Considerando que o professor precisa estar relativamente ciente do contexto científico da época, é importante que ele conheça essas informações e possa estimular a curiosidade dos alunos a respeito do que não está no texto: $\mathrm{O}$ que poderia ser? O que essa repugnância pode significar? ${ }^{17}$

A narrativa propõe o desafio da interpretação, trazendo indeterminação adequada e suficiente para levar o leitor ao diálogo (DOLL JR, 1997 apud RIBEIRO; MARTINS, 2007, p. 294). Ademais, é significativo notar que a situação vivenciada, isto é, realizar questionamentos e propor hipóteses para possível investigação posterior lembra o ofício do próprio historiador da ciência em contato com fontes primárias. Não raro, o historiador se depara com documentos os quais compreende apenas parcialmente e busca interpretá-los (MARTINS, 1993).

Analogamente, o aluno tem à sua frente elementos que podem ser compreendidos e outros que podem eventualmente ser registrados para investigação posterior. Vivencia uma si-

\footnotetext{
${ }^{17}$ Dentre possíveis textos de apoio sobre a temática histórica dos quais os professores podem se beneficiar estão: MARTINS, 1989; SOLAZ-PORTOLÈS; MORENO-CABO, 1997; LONGHINI; NARDI, 2002; PORTELA, 2006; LONGHINI; NARDI, 2009; OLIVEIRA, 2013. Em inglês, sugere-se GRANT, 1981.
} 
tuação que gera curiosidade sobre os acontecimentos envolvendo o episódio histórico. Um entendimento parcial virá na próxima questão da entrevista, enquanto outras perguntas ficam ainda sem resposta. Nesse sentido, o professor, conhecendo aspectos do contexto científico da época, pode trazer certos esclarecimentos, caso julgue conveniente ${ }^{18}$.

\section{Terceiro bloco}

Jornalista: Mas se o vácuo existe, ele não seria a causa da sustentação da coluna de mercúrio? Ele não daria um puxão, como dizem? Para o senhor, então, o que sustenta a coluna de mercúrio?

Torricelli: "Costuma ser dito como explicação para o fato de que o tubo AE permanece vazio e o mercúrio, embora pesado, seja sustentado no tubo AC, que, como se acredita até agora, a força que impede que o mercúrio caia, como naturalmente o faria, é interna ao tubo AE, e provém do vácuo ou de alguma substância extremamente rarefeita; mas afirmo que é externa, e que essa força vem de fora".

Vários pensadores justificavam o resultado do experimento como sendo uma tentativa da natureza de não formar vazio dentro do tubo ou de permiti-lo parcialmente. Haveria uma força interna, causada pelo vazio, que seguraria o mercúrio dentro do tubo - "força do vácuo". A pergunta que compõe a suposta entrevista foi elaborada no sentido de colaborar para que o leitor compreenda essa visão à qual Torricelli se opõe. Utiliza palavras mais simples como "puxão" para transcrever em linguagem acessível ao aluno essa outra interpretação para a sustentação da coluna de mercúrio.

É importante notar em aula que no trecho escrito por Torricelli a referência a uma causa de sustentação externa aparece como uma interpretação firme do próprio pensador: "eu afirmo". Assim, nota-se a intenção de Torricelli de transmitir confiança quanto a essa interpretação, ainda que, como ele mesmo reconhece, esta represente uma divergência em relação a uma interpretação mais tradicional ("Costuma ser dito").

Em eventual utilização didática da entrevista, pode ser relevante privilegiar na discussão elementos como: a compreensão das duas interpretações; a intencionalidade do pesquisador ao se expressar daquela forma específica; qual seria a interpretação mais tradicional e qual seria a divergente; a possibilidade de existência de diferentes explicações para um mesmo fenômeno natural, sendo esse um importante aspecto da Natureza da Ciência.

Tais elementos se contrapõem ao que se costuma notar nos livros didáticos, os quais de forma simplista trazem exclusivamente a interpretação de Torricelli como uma "descoberta" importante revelada pelo experimento. Esses elementos contrastam diretamente com uma concepção empírico-indutivista e a-teórica da ciência (GIL PÉREZ et al., 2001, p.129). Como o próprio Torricelli demonstra, o experimento não revelava "a atuação de uma força externa". $\mathrm{O}$

\footnotetext{
${ }^{18}$ Poderia também prosseguir deixando questões pendentes para outros momentos, em caso de eventual utilização de outras edições do jornal histórico (BATISTA, 2014).
} 
experimento por si só não afirmava nada. Ele sim, Torricelli, o fazia e, ao fazê-lo, contrapunhase a uma corrente de pensamento mais tradicional.

Assim, quando os livros didáticos afirmam que ele "corretamente" fez certas afirmações sobre o experimento do mercúrio ${ }^{19}$, pode-se dizer que vem à tona uma afirmação anacrônica. O "corretamente" advém de comparação e julgamento de valor à luz do que é aceito atualmente. Em contraposição, sob o ponto de vista da época, a afirmação de Torricelli era dissidente, havendo possibilidades mais aceitas.

A afirmação de Torricelli pode servir de contexto para se problematizar a visão ingênua de ciência linear e acumulativa, comum nos ambientes escolares, uma vez que não costuma haver referência "às frequentes confrontações entre teorias rivais, às controvérsias científicas, nem aos complexos processos de mudança" (GIL PÉREZ et al., 2001, p. 132-133). É inerente ao encaminhamento sugerido, por outro lado, que transpareça o caráter mutável do conhecimento científico, a possibilidade de rupturas com interpretações aceitas pela coletividade.

\section{Quarto bloco}

Jornalista: Como assim? Que força seria essa?

Torricelli: "Vivemos imersos no fundo de um oceano de ar elementar, o qual, por experimento, sem dúvida tem peso, e tanto peso que o ar mais denso na vizinhança da superfície da terra pesa cerca de uma quatro-centésima parte do peso da água. Esse peso, determinado por Galileo, podemos considerar que se aplique à atmosfera mais baixa, onde os homens e os animais vivem, enquanto que nos picos das altas montanhas o ar começa a se tornar mais puro e a pesar muito menos do que a quatrocentésima parte do peso da água. No nosso caso, estamos realizando o experimento na superfície da terra. Sobre a superfície do líquido que está na bacia repousa o peso de uma [coluna del altura de cinquenta milhas de ar; então, e se no tubo CE, no qual o mercúrio não sofre tendência ou repugnância alguma, nem mesmo mínimas, a estar lá, devesse entrar e subir uma coluna alta o suficiente para entrar em equilíbrio com o peso do ar exterior que o força a subir?"

A pergunta elaborada para composição da entrevista indica que o trecho escrito por Evangelista Torricelli visa esclarecer que força externa, na opinião do pensador, seria aquela responsável pelo fenômeno observado: o peso do ar atuando na superfície do líquido na bacia.

Em sua explicação, Torricelli recorre à consideração de que o ar possui peso. Esse é o primeiro trecho da entrevista que nos remete explicitamente ao elemento pressão atmosférica. Com base nesse elemento, o pensador está propondo algo complexo e delicado: a possível substituição de uma tradicional explicação do experimento com base no horror ao vácuo. Enfim,

\footnotetext{
${ }^{19}$ A título de exemplo, pode-se citar: "Torricelli concluiu corretamente que essa coluna de mercúrio era equilibrada pela pressão atmosférica exercida na superfície livre da cuba, ao nível do mar, onde realizou o experimento" (GASPAR, 2011, p. 333; ênfase nossa).
} 
Torricelli não está simplesmente medindo a pressão atmosférica, mas sim se debruçando sobre o problema da sustentação da coluna de mercúrio. Esse aspecto pode ser explorado pelo professor, sendo algo distinto e mais aprofundado do que os livros didáticos costumam trazer.

É interessante notar, ainda, que Evangelista Torricelli parece intencionalmente defender o pressuposto que toma como ponto de partida: o peso do ar. Essa peça-chave usada por Torricelli precisa ser explicada e defendida por ele, o que indica seu caráter não óbvio e ainda não consolidado na época. Deve ser observado, ainda, que Torricelli recorre ao trabalho de Galileo, o que revela o caráter cooperativo da ciência.

Ainda no que diz respeito a esse trecho, Torricelli afirma que vivemos imersos em um oceano de ar. O que isso quer dizer? De onde Torricelli tirou essa conclusão? Será que o aluno concorda com isso? Por que não somos, então, esmagados por esse oceano de ar?

Esta não costuma ser uma questão óbvia para o aluno, tal como não foi óbvia ao longo do desenvolvimento da própria História da Ciência ${ }^{20}$. Nesse sentido, o professor pode perceber e tentar esclarecer eventuais dificuldades ${ }^{21}$.

Voltando à resposta de Torricelli, o pensador relata seu entendimento de que aumentando a altitude (no alto das montanhas) o ar se torna mais rarefeito. Será que os alunos já vivenciaram essa situação ou conhecem alguma informação sobre isso? Sobre esse questionamento, é possível discutir o que ocorre quando times de futebol vão jogar em locais de grandes altitudes, ou o que significaria pressurizar uma cabine de avião, etc.

Finalizando esse trecho da entrevista, possíveis questionamentos abririam caminho para utilização subsequente da correspondência sobre o Puy-de-Dôme: O que ocorreria se Torricelli fosse realizando o experimento à medida que subisse uma montanha? O que esperaria ocorrer com a coluna de líquido? A intenção, nesse caso, não seria conduzir uma discussão a fim de obter respostas, mas sim hipóteses que seriam registradas para discussão posterior.

\section{Quinto bloco}

Jornalista: Mas mesmo considerando que o ar tem peso e atua sobre o mercúrio, ainda assim poderíamos considerar que aquele espaço vazio ou com alguma substância bem rarefeita tem alguma influência na altura da coluna de mercúrio?

Torricelli: "A água em um tubo similar, embora mais longo, subirá até cerca de 18 cúbitos, isto é, [sobel tanto mais do que aquilo que o mercúrio sobe, o quanto ele é mais pesado do que a água; de forma a haver um equilíbrio com a mesma causa que atua sobre um e sobre o outro. Este argumento é reforçado por um experimento feito

\footnotetext{
${ }^{20}$ Lembrando afirmação de Saltiel e Viennot (1985, p.144): “[...] a História da Ciência, através das resistências que se manifestam ao longo do tempo, nos dá uma boa oportunidade para não subestimar as dificuldades de nossos estudantes. Também indica que certos conceitos e noções não deveriam ser introduzidos demasiado rapidamente".

${ }^{21}$ Caso seja conveniente, o professor pode encaminhar questionamento a respeito da analogia água-ar trazida à tona por Torricelli. A edição IV do jornal explica que a analogia foi realizada por Stevin, mestre de Torricelli: a água teria peso e pressionaria os corpos imersos nela, o mesmo ocorrendo com o ar (BATISTA, 2014). Novamente transparece o caráter cooperativo da ciência.
} 
simultaneamente com o tubo A e com o tubo $B$, no qual o mercúrio sempre permanece na mesma linha horizontal AB. Isso deixa quase que certo que a ação não se origina de dentro; por que o vaso AE, onde haveria mais substância rarefeita, deveria ter exercido uma força maior, atraindo muito mais ativamente, por causa da maior rarefação, do que se observa no espaço menor B. Tenho me empenhado em explicar por esse princípio todos os tipos de repugnâncias que são sentidas em vários efeitos atribuídos ao vácuo, e ainda não encontrei alguma com a qual não consiga lidar com sucesso. [...] parece-me tolice tentar atribuir ao vácuo aquelas operações que se seguem evidentemente de alguma outra causa".

Nesse trecho, Evangelista Torricelli reafirma o posicionamento de aceitar a interpretação de que a causa para a sustentação do mercúrio é externa, e não interna. Utiliza novamente um argumento empírico: se a causa fosse o puxão do vazio ou a atuação de uma substância rarefeita presente no espaço superior do tubo, no tubo com um espaço superior maior a coluna de mercúrio também deveria ser maior, o que não era observado. Tubos com diferentes espaços superiores tinham a coluna de mercúrio a uma mesma altura.

A pergunta elaborada para a composição da entrevista traz à tona aspectos importantes relacionados ao desenvolvimento do conhecimento científico: o uso de argumentos de simplicidade, como a navalha de Ockham. Torricelli reconhece que ainda vem estudando o assunto e sustenta seu discurso com base em argumento de simplicidade. Estudando caso a caso, ele notava que a explicação baseada na atuação da pressão do ar explicava a sustentação da coluna de mercúrio. Era adequada e suficiente, não sendo necessário recorrer a causas adicionais. Em vista disso, outras explicações poderiam ser abandonadas. Seria tolice atribuir algum papel ao vácuo nesse sentido. Seria desnecessário.

\section{Sexto bloco}

Jornalista: Parece que o senhor realmente está interessado nesse assunto. Por quê? Torricelli: "Eu e vários senhores com os quais tenho me correspondido como os senhores Michelangelo Ricci, Antonio Nardi e Magiotti. Escrevi ao senhor Ricci relatando os resultados que agora lhe apresentei. Disse a ele: "irá perceber muitas objeções, mas espero que se o senhor pensar sobre elas, as mesmas sejam resolvidas". Eu já havia chamado a atenção para o fato de que estão sendo realizados certos experimentos filosóficos, não sei exatamente o que, relacionados ao vácuo, elaborados não simplesmente para produzir vácuo, mas para chegar a um instrumento que nos mostrará as mudanças na atmosfera, se está agora mais pesada e densa e depois mais leve e sutil”.

A cooperação é um aspecto importante da atividade científica evidenciado por Evangelista Torricelli em seus escritos. O pensador cita a participação de outros colegas na discussão e condução de experimentos relacionados ao vácuo e em tentativas de entender as mudanças na 
atmosfera. É possível, então, incentivar a percepção de aspectos que costumam ser deixados de lado por livros didáticos: a cooperação, já que a ciência não é feita por gênios isolados; e, no caso específico desse conteúdo, que os experimentos não surgiram de repente como uma tentativa de medir a pressão atmosférica, essa questão se relacionava a uma discussão sobre o vácuo que vinha movendo a comunidade de pesquisadores há certo tempo.

\section{Sétimo bloco}

Jornalista: Estudar as mudanças na atmosfera... mas, isso seria ótimo! O senhor está encontrando alguma dificuldade na realização desse trabalho? Já tem resultados convincentes?

Torricelli: "Exatamente. Minha intenção principal é reconhecer quando a atmosfera é mais densa e mais pesada e quando é mais sutil e mais leve. Mas ainda não fui capaz de concretizá-la porque o nível AB no instrumento EC varia por alguma outra razão, o que eu não teria acreditado, especialmente como se fosse sensivel ao frio ou ao calor, exatamente como se o tubo AE estivesse cheio de ar".

Jornalista: Isso é estranho... O senhor não disse que o tubo estava vazio? Bem, não quero aborrecê-lo. Sabemos que essa é uma pergunta muito complicada. E que, por outro lado, é justamente a dúvida e não a certeza que estimula pesquisador. Nossos leitores agradecem ao ilustre pesquisador e vamos continuar acompanhando de perto suas pesquisas!

A fala do jornalista, elaborada para a composição da entrevista, pretende trazer à tona aspectos que podem ser abordados em aula e que fogem à afirmação simplista de que Torricelli de repente mediu a pressão atmosférica.

No trecho transcrito para a entrevista, Torricelli reconhece que tinha dificuldades e não havia chegado a uma conclusão final. Havia questões que ele não conseguia explicar. Manifestava a intenção de entender o comportamento da atmosfera, mas o caminho dessa investigação não era simples, não resultava no que havia previsto. Muito pelo contrário, o trecho final da fala de Torricelli poderia até mesmo servir aos adversários já que sugeria que algo interno ao tubo tinha algum efeito no que se observava. Por outro lado, Torricelli não parecia desanimado e sim estimulado pelo desafio. Assim, detalhes que trazem à tona o caráter humano da pesquisa científica podem ser contemplados na discussão desse trecho. O pesquisador aparece de certa forma em situação caracterizada por elementos vivenciados pelos próprios alunos: faz perguntas, hesita, tem dúvidas. 


\section{Possibilidade de utilização didática da correspondência sobre o experimento do Puy- de-Dôme}

Os livros didáticos costumam apresentar lacunas significativas em relação à construção histórica do conceito de pressão atmosférica. Na presente seção, sugere-se a utilização didática da correspondência sobre o experimento do Puy-de-Dôme de forma a contemplar algumas dessas lacunas.

O Apêndice 3 apresenta uma tradução proposta pelos autores do presente artigo para correspondência datada de 1648, na qual Florin Périer, cunhado de Blaise Pascal, relata a esse pesquisador a realização do experimento de Torricelli em variadas condições climáticas (chuva, sol, etc.), e, em diferentes altitudes, ao longo da montanha Puy-de-Dôme, na França. A realização do experimento havia sido solicitada por Pascal, nascido na cidade de Clermont (atual Clermont-Ferrand), onde se localiza o Puy-de-Dôme. Pascal reage de forma entusiasmada ao relato.

A linguagem da comunicação entre os personagens é simples e acessível aos estudantes da educação básica, podendo a tradução ser utilizada de forma integral em sala de aula do Ensino Médio. Diante da perspectiva de certa autonomia, propõe-se a "aventura" de ler a correspondência.

Os leitores-alunos são convidados a refletir sobre o desenvolvimento de uma ciência, cujo dinamismo é ressaltado. Dessa forma, a correspondência pode ser utilizada em sala de aula de forma a se contrapor a uma perspectiva que vem sendo criticada no ensino científico: "a apresentação de conhecimentos previamente elaborados, sem dar oportunidade aos estudantes de contactarem e explorarem atividades na perspectiva de um ensino do tipo investigativo" (GIL PÉREZ et al., 2001, p. 126).

Sugere-se, por outro lado, a utilização da correspondência entre Périer e Pascal em perspectiva investigativa. Tendo em vista estimular a imaginação e encorajar a investigação a respeito do conteúdo da carta, sugere-se atividade dialógica que busque valorizar as impressões dos próprios estudantes. O professor pode atuar como mediador, sugerindo questões diversas ${ }^{22}$ :

- O que chamou sua atenção primeiramente? O que você notou que não saberia explicar?

- Quem está escrevendo? Há uma resposta para essa carta?

- Como você imagina os locais apontados no texto? Por que você acha que esses locais foram escolhidos para o desenvolvimento do experimento? Por que será que estavam naquele tipo de local? Como você chegou a essa conclusão?

- Quem você imagina que sejam essas pessoas? Você já ouviu falar sobre eles?

- Como você imagina o contexto histórico no qual foram escritas essas palavras?

\footnotetext{
${ }^{22}$ Alguns desses questionamentos são inspirados pelo Teaching with Primary Sources Quarterly (LIBRARY OF CONGRESS, 2011). Certos detalhes, como as unidades de medida usadas no passado, podem chamar a atenção dos estudantes. Ainda que discuti-los não faça parte dos objetivos didáticos previstos pelo professor, deveriam ser valorizados, registrados para investigação posterior da turma.
} 
- O que a carta descreve? O que estavam fazendo? O que você imagina que estava acontecendo quando o experimento foi feito? Qual aparenta ser o objetivo ao realizar todo o procedimento?

- Parece ser algo importante para eles?

- A que questionamentos estavam tentando responder? Que relação há entre o que estavam fazendo e o experimento de Torricelli?

- Qual seria a intenção com a realização dos experimentos? O que pareciam buscar? Estavam investigando alguma hipótese?

- A que conclusões chegam? Como reagiram diante dos resultados?

- Aparece um padre em uma das cartas... Qual o papel do padre?

- Que impressão sobre a realização do experimento Périer procurou transmitir?

O resultado desse experimento, segundo essas pessoas, apoiaria a visão de Torricelli de que a causa da sustentação da coluna de mercúrio seria externa? Que causa seria essa, na opinião desses investigadores?

- O que você percebeu que não sabia anteriormente? O que você pôde aprender ao ler essas cartas? O que você notou que não esperava encontrar?

O professor pode orientar a investigação de possíveis hipóteses sobre o episódio histórico, bem como estimular a elaboração de questões pelos próprios alunos. Os estudantes podem ser encorajados a investigar sobre aspectos relacionados ao processo de construção do conhecimento científico, percebendo-o como empreendimento humano. Adicionalmente, podem ser instigados a inquirir acerca das intenções dos personagens ao produzirem os relatos.

Abre-se espaço para uma possível reflexão sobre a laboriosa busca de soluções para problemas na ciência, o empenho dos pesquisadores, a construção coletiva do conhecimento e a articulação entre teoria e experimento. Pode-se, inclusive, numa perspectiva diacrônica, estabelecer o diálogo entre passado e presente. Pode-se perceber a confiança representada pela presença de religioso durante aquele procedimento experimental e a ausência de participação feminina. Como seriam tais aspectos numa atividade científica atual?

A correspondência pode ser utilizada sem que haja conhecimento inicial dos alunos acerca de quem a escreveu, quando foi escrita, quem eram os personagens envolvidos, qual o interesse de cada um na realização dos experimentos, etc. Nessas circunstâncias, os alunos são convidados a gerar hipóteses acerca do material que possuem em mãos.

As informações sobre os personagens não aparecem na carta. A relação com o experimento de Torricelli não é explícita, mas pode ser estabelecida pelos próprios alunos. Pode-se, assim, mediar a compreensão de que problemas propostos por um pesquisador estimulam o interesse de outros, em contraposição a uma visão individualista da ciência.

O local citado na correspondência possivelmente não é conhecido pelos alunos, mas é interessante que procurem imaginar de que tipo de local se trata. Pode-se defender justamente 
que o professor não propicie de antemão tais informações e nem as forneça prontamente caso seja questionado. Sugere-se que os alunos recorram ao que viram anteriormente a fim de interpretar e elaborar hipóteses sobre o documento.

Não imediatamente, portanto, mas à medida que os alunos apresentam suas impressões, formulam e discutem hipóteses sobre o assunto pode, então, ser interessante utilizar imagens relacionadas a personagens e locais citados na carta.

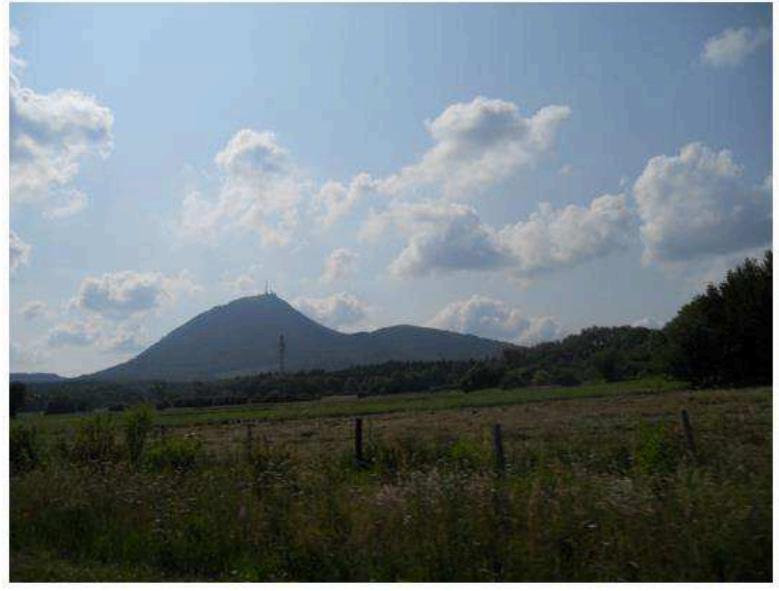

Fig. 1 - O Puy-de-Dôme, foto atual a partir de estação turística ao pé da montanha.

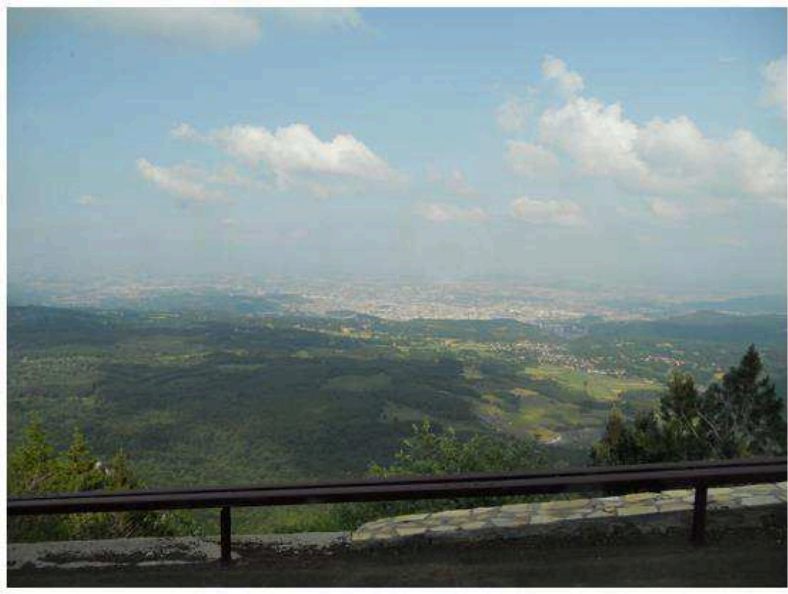

Fig. 2 - Foto atual tirada na subida do Puy-de-Dôme, vê-se ao fundo a atual cidade de Clermont-Ferrand.

(Fonte: Acervo particular dos autores)

Uma possibilidade interessante seria solicitar que os próprios alunos buscassem imagens em sites na internet, de forma que pudessem trazê-las para discussão: Qual a altura do Puy-de-Dôme? Teria sido difícil subi-lo?

A própria dificuldade de obtenção de determinadas imagens pode incitar discussões relevantes. Pode-se, por exemplo, desafiar a turma a encontrar imagens de Blaise Pascal e Florin Périer. É significativo notar que imagens de Pascal são obtidas com facilidade, mas o mesmo não ocorre em relação a Périer (Fig. 3). Esse detalhe curioso pode ser relevante para desencadear em aula discussão sobre a cooperação na ciência e, ao mesmo tempo, a importância da colaboração de personagens cujos nomes não costumam ser lembrados.

A atividade de cunho investigativo a respeito da correspondência sobre o Puy-deDôme permite, ainda, percepções não usuais no contexto das propostas para inserção didática da História e Filosofia da Ciência: o significado desse tipo de documento para História da Ciência e a impossibilidade de acesso direto ao passado.

Pode-se mediar discussão que traga à tona a percepção de que não é possível sabermos através das fontes primárias como o passado realmente foi. Fontes primárias repercutem as intencionalidades dos personagens: Como Périer e Pascal vivenciaram o experimento do Puy- 
de-Dôme? O que disseram ou quiseram dizer a respeito dele naquelas circunstâncias? Como o fizeram?

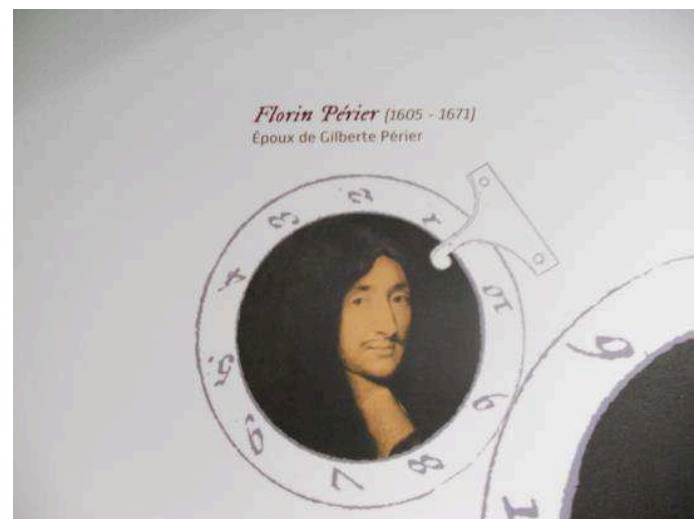

Fig. 3 - Rara imagem de Florin Périer. Fonte: Foto do arquivo pessoal dos autores obtida de exposição atual no Museu Henri LeCoq, de Clermont-Ferrand.

Assim, a leitura das cartas nos permite interpretar como o experimento do Puy-deDôme foi relatado por Périer e Pascal. Pode-se, ainda, mediar a compreensão de que as fontes primárias podem ser interpretadas de diferentes formas por quem as lê. A interpretação depende inclusive se o leitor dispõe ou não de informações adicionais: Se não tivéssemos lido a entrevista de Torricelli, ou seja, se não tivéssemos conhecimento das discussões anteriores, o que entenderíamos desse documento? Como buscaríamos informações para compreendê-lo?

Atividades que contemplem tais objetivos podem ser desenvolvidas inclusive de forma interdisciplinar, com o professor de História, tendo em vista que percepções relacionadas à escrita da História são citadas na legislação educacional para essa disciplina escolar (CAIMI, 2008). Para a HFC no Ensino, abrem-se, assim, novas perspectivas no tocante ao uso didático de fontes primárias.

\section{Considerações finais}

A utilização de episódios históricos vem sendo reforçada como caminho para discutir sobre o processo de construção da ciência no contexto educacional. Advoga-se a importância de que a ciência seja percebida como produção humana, construída coletivamente por seres humanos e não por gênios isolados. Sugere-se a necessidade de compreender melhor a natureza dos embates científicos. Afirma-se que a abordagem histórico-filosófica contribuiria para uma aprendizagem mais aprofundada dos próprios conceitos ao permitir associá-los a problemas que lhes deram origem.

No âmbito das propostas para a HFC no Ensino são ainda escassas iniciativas de intervenções didáticas que utilizem fontes primárias. Por outro lado, observa-se significativo potencial didático sinalizado pelas raras iniciativas nesse sentido. 
Para efetivamente explorar tais potencialidades é necessário lidar com certos entraves peculiares. A utilização didática desse tipo de material implica escolher excertos potencialmente relevantes, adequados ao contexto educacional visado, obter boas traduções e buscar alternativas para contornar eventuais dificuldades de compreensão.

Em termos mais gerais, merecem significativa ampliação e aprofundamento as discussões de cunho teórico sobre a inserção didática de fontes primárias. Certos aspectos começam a ser identificados pela literatura:

[...] acreditamos no potencial dos textos originais como instrumento de ensino; no entanto, ressaltamos que sua plena utilização pressupõe uma articulação entre conceitos, questões históricas e filosóficas, que não pode ser desfeita, pois está implícita em sua própria estrutura [...] (DION; LOURES, 2013, p. 201).

É necessário refletir sobre para quê e como utilizá-las. Uma perspectiva investigativa, e não meramente ilustrativa, está, ao mesmo tempo, em ressonância com pressupostos historiográficos e objetivos didáticos atualizados. Permite reconhecer o caráter interpretativo da História da Ciência. Promove a percepção de que as intencionalidades dos personagens envolvidos nos episódios relatados podem ser interpretadas com auxílio de elementos contextuais, o que, por sua vez, incentiva a curiosidade e a imaginação dos alunos acerca do processo de construção do conhecimento. Evoca elementos usualmente ausentes nos materiais didáticos. Impulsiona a percepção de uma ciência “viva”. Permite relacionar conceitos científicos a seres humanos.

Como exemplos, o presente artigo trouxe duas propostas para a inserção didática de fontes primárias da História da Ciência que podem ser ampliadas para outros episódios e documentos históricos. Na primeira proposta, trechos de uma carta original de um pesquisador foram envolvidos por elementos narrativos que colaboram para a sua cognoscibilidade. Já na segunda proposta, prevê-se que a correspondência entre personagens que descrevem um experimento possa ser utilizada diretamente em sala de aula, em versão traduzida para o vernáculo.

As propostas surgem como recursos adicionais ao livro didático na medida em que são introduzidas por questionamentos acerca do processo de construção histórica dos conceitos físicos. Sugere-se a condução de atividades investigativas, dialógicas, baseadas na interpretação diacrônica dos documentos sob a mediação do professor. Não há um roteiro a seguir, mas sugestões adaptáveis a necessidades pedagógicas e contextos educacionais. Reforça-se a importância do papel do professor na flexibilização dessas sugestões. Não é razoável pretender que os mesmos se tornem historiadores da ciência, mas é preciso que estejam conscientes quanto ao uso criterioso das fontes primárias. A atenção a pressupostos historiográficos é um aspecto significativo, nesse sentido.

\section{Referências}

ALFONSO-GOLDFARB, A. M. O que é história da ciência. São Paulo: Brasiliense, 1994. 93p. 
BAGDONAS, A.; SILVA, C. C. Controvérsias sobre a natureza da ciência na educação científica. In: SILVA, C. C.; PRESTES, M. E. B (Eds.). Aprendendo ciência e sobre sua natureza: abordagens históricas e filosóficas. São Carlos: Tipographia, 2013. p. 213-224.

BATISTA, R. P.; MOHR, A.; FERRARI, N. A análise da história da ciência em livros didáticos do ensino fundamental em Santa Catarina. In: ENCONTRO NACIONAL DE PESQUISA EM EDUCAÇÃO EM CIÊNCIAS, 6, 2007, Florianópolis, SC. Anais... ABRAPEC, 2007. Disponível em: <http://www.nutes.ufrj.br/abrapec/vienpec/CR2/p380.pdf>. Acesso em: 8 jul. 2014.

BATISTA, G. L. F. Fontes Primárias da História do Vácuo e da Pressão Atmosférica na Sala de Aula: cartas e jornais históricos em articulação com o livro-texto do Ensino Médio. 2014. Dissertação (Mestrado) - UFRN. Disponível em:

<http://repositorio.ufrn.br:8080/jspui/handle/123456789/16115 >. Acesso em: 7 set. 2015.

BEZERRA, E. V. L. Análise de propostas didáticas de história e filosofia da ciência para o ensino de física. 2014. Dissertação (Mestrado) - UFPR. Disponível em: <http://www.ppgecm.ufpr.br/Dissertações/040_EvaldoVictorLimaBezerra.pdf>. Acesso em: 7 mai. 2015.

BOAS, A. V.; SILVA, M. R.; PASSOS, M. M.; ARRUDA, S. M. História da Ciência e Natureza da Ciência: debates e consensos. Caderno Brasileiro de Ensino de Física, Florianópolis, v. 30, n. 2, p. 287-322, ago. 2013. Disponível em: <https://periodicos.ufsc.br/index.php/fisica/article/view/2175-7941.2013v30n2p287>. Acesso em: 17 mai. 2015.

BONJORNO, J. R. et al. Física: História \& Cotidiano. São Paulo: Editora FTD, 2003. v. 1.

BOSS, S. L. B.; SOUZA FILHO, M. P.; CALUZI, J. J. Fontes Primárias e Aprendizagem Significativa: Aquisição de subsunçores para aprendizagem do conceito de carga elétrica. In: ENCONTRO NACIONAL DE PESQUISA EM EDUCAÇÃO EM CIÊNCIAS, 7, 2009, Florianópolis, SC. Anais... ABRAPEC, 2009. Disponível em: <http://posgrad.fae.ufmg.br/pos$\mathrm{grad} / \mathrm{viienpec/pdfs/1717.pdf}>$. Acesso em: 17 mai. 2015.

Traduções de fonte primária - algumas dificuldades quanto à leitura e o entendimento. In: ENCONTRO NACIONAL DE PESQUISA EM EDUCAÇÃO EM CIÊNCIAS, 8, 2011, Campinas, SP. Anais... ABRAPEC, 2011. Disponível em: <http://www.nutes.ufrj.br/abrapec/viiienpec/resumos/R0441-1.pdf >. Acesso em: 17 mai. 2015.

BOSS, S. L. B. Tradução Comentada de Artigos de Stephen Gray (1666-1736) e reprodução de experimentos históricos com materiais acessíveis: subsídios para o ensino de eletricidade. 2011. Tese (Doutorado) UNESP. Disponível em: <http://www2.fc.unesp.br/BibliotecaVirtual/ArquivosPDF/TES_DOUT/TES_DOUT20121205_BOSS\%20SER-

GIO\%20LUIZ\%20BRAGATTO.pdf>. Acesso em: 05 mai. 2013. 
. Considerações sobre a produção e o uso de material histórico em sala de aula: dificuldades de leitura e entendimento de traduções de fontes primárias. In: CAMARGO et al. (Org.). Controvérsias na Pesquisa em Ensino de Física. São Paulo: Editora Livraria da Física, 2014. p. 161-176.

BRASIL, Ministério da Educação - MEC, Secretaria de Educação Média e Tecnológica - SEMTEC. Parâmetros Curriculares Nacionais para o Ensino Médio. Brasília: MEC/SEMTEC, 1999.

BRICCIA, V.; CARVALHO, A. M. P. Visões sobre a Natureza da Ciência construídas a partir do uso de um texto histórico na escola média. Revista Electrónica de Enseñanza de las ciencias, v. 10, n. 1, p. 1-22, 2011. Disponível em: <http://reec.uvigo.es/volumenes/volumen10/ART1_Vol10_N1.pdf >. Acesso em: 17 mai. 2015.

BUENO, M. C. F.; PACCA, J. L. A. Combinando a leitura de originais da ciência com outras atividades para construir o conhecimento na sala de aula. In: ENCONTRO NACIONAL DE PESQUISA EM EDUCAÇÃO EM CIÊNCIAS, 7, 2009, Florianópolis, SC. Disponível em: <http://posgrad.fae.ufmg.br/posgrad/viienpec/pdfs/927.pdf>. Acesso em: 17 mai. 2015.

CAIMI, F. E. Fontes históricas na sala de aula: Uma possibilidade de produção de conhecimento histórico escolar? Anos 90, Porto Alegre, v. 15, n. 28, p. 129-150, dez. 2008. Disponível em: <http://seer.ufrgs.br/anos90/article/view/7963 >. Acesso em: 17 mai. 2015.

CHALMERS, A. O que é ciência afinal? São Paulo: Editora Brasiliense, 1993. 224 p.

CLOUGH, M. P.; OLSON, J. K. Teaching and assessing the nature of science; an introduction. Science \& Education, Dordrecht, n. 17, p. 143-145, 2008.

DION, S. M.; LOURES, M. V. R. O debate realismo/antirrealismo em situações de ensino de física, à luz da interface entre história e filosofia da ciência. In: SILVA, C. C.; PRESTES, M. E. B. (Org.) Aprendendo ciência e sobre sua natureza: abordagens históricas e filosóficas. São Carlos: Tipographia, 2013. p. 193-208.

DOCA, R. H.; BISCUOLA, G. J.; BÔAS, N. V. Tópicos de Física. São Paulo: Editora Saraiva, 2007. v. 1.

FERraro, N. G., SOARES, P. A. de T. Aulas de Física 1: Mecânica. São Paulo: Editora Atual, 2003. v. 1.

FORATO, T. C. M. A natureza da ciência como saber escolar: um estudo de caso a partir da história da luz. 2009. 420 f. Tese (Doutorado em Educação) - Faculdade de Educação, USP, São Paulo.

FORATO, T. C. M.; MARTINS, R. A.; PIETROCOLA, M. Historiografia e Natureza da Ciência na sala de aula. Caderno Brasileiro de Ensino de Física, Florianópolis, v. 28, n. 1, p. 27 - 
59, abr. 2011. Disponível em: <https://periodicos.ufsc.br/index.php/fisica/article/view/21757941.2011v28n1p27 >. Acesso em: 17 mai. 2015.

History and Nature of Science in High School: Building Up Parameters to Guide Educational Materials and Strategies. Science \& Education, Dordrecht, v. 21, p. 657-682, 2012. (a)

Enfrentando obstáculos na transposição didática da história da ciência para a sala de aula. In: PEDUZZI, L. O. Q.; MARTINS, A. F. P., FERREIRA, J. M. H. (Org.). Temas de história e filosofia da ciência no ensino. Natal: EDUFRN, 2012. cap. 5, p. 123-154. (b)

GASPAR, A. Física - Mecânica. Editora Ática, São Paulo, 2001. v. 1.

Física. São Paulo: Editora Ática, 2011. v. único.

GIL PÉREZ, D. et al. Para uma imagem não deformada do trabalho científico. Ciência \& Educação, Bauru, v. 7, n. 2, p. 125-153, 2001. Disponível em: <http://www.scielo.br/pdf/ciedu/v7n2/01.pdf>. Acesso em: 17 mai. 2015.

GRANT, E. Much ado about nothing: theories of space and vacuum from the Middle Ages to the Scientific Revolution. Cambridge: Cambridge University Press, 1981.

GUERRA, A. A identidade e o diálogo como possibilidade de superação da controvérsia entre educadores e historiadores da ciência. In: CAMARGO et al. (Org.). Controvérsias na Pesquisa em Ensino de Física. São Paulo: Livraria da Física, 2014. cap. 6, p. 129-142.

HÖTTECKE, D.; SILVA, C. C. Why Implementing History and Philosophy in School Science Education is a Challenge: An Analysis of Obstacles. Science \& Education, Dordrecht, v. 20, p. 293-316, 2010.

JUNIOR, F. R.; FERRARO, N. G.; SOARES, P. A. de T. Os fundamentos da Física. São Paulo: Editora Moderna, 2007. v. 1.

KOSMINSKY, L.; GIORDAN, M. Visões de ciências e sobre cientista entre estudantes do ensino médio. Química Nova na Escola, São Paulo, v. 15, s/n, p. 11-18, 2002. Disponível em: <http://qnesc.sbq.org.br/online/qnesc15/v15a03.pdf>. Acesso em: 17 mai. 2015.

LARANJEIRAS, C. A educação científica na convergência de práticas educativas cientificamente referenciadas. In: CAMARGO et al (Org.). Controvérsias na Pesquisa em Ensino de Física. São Paulo: Livraria da Física, 2014. cap. 9, p. 177-189.

LEDERMAN, N. G. Nature of science: past, present and future. In: ABELL, S.K.; LEDERMAN, N. G. (Eds.). Handbook of Research on Science Education. Mahwah, New Jersey: Lawrence Erlbaum Publishers, 2007. cap. 28. p. 831-880. 
Nature of scientific knowledge and scientific inquiry: building instructional capacity through professional development. In: FRASER, B. J.; TOBIN, K. J.; MCROBBIE, C. (Eds.). Second International Handbook of Science Education. Dordrecht, London: Springer, 2012. p. 335-360. v. 1 .

LIBRARY OF CONGRESS. Teaching with primary sources quarterly. USA, 2011. Disponível em: <http://www.loc.gov/teachers/tps/>. Acesso em: 10 jan. 2015.

LONGUINI, M. D.; NARDI, R. Origens históricas e considerações acerca do conceito de pressão atmosférica. Caderno Brasileiro de Ensino de Física, v. 19, n. 1, p. 67-78, abr. 2002. Disponível em: <https://periodicos.ufsc.br/index.php/fisica/article/view/9295 >. Acesso em: 17 mai. 2015.

Como age a pressão atmosférica? Algumas situações-problema tendo como base a história da ciência e pesquisas na área. Caderno Brasileiro de Ensino de Física, v. 26, n. 1, p. 7-23, abr. 2009. Disponível em: <http://www.educadores.diaadia.pr.gov.br/arquivos/File/2010/artigos_teses/2010/Ciencias/Artigos/50pressao_atmosferica.pdf >. Acesso em: 17 mai. 2015.

MAGIE, W. F. A source book in Physics. Cambridge, MA: Harvard University Press, 1969.

MARTINS, R. A. O vácuo e a pressão atmosférica, da antiguidade a Pascal. Caderno de História e Filosofia da Ciência, Campinas, série 2, n. Especial, p. 9-48, 1989.

Abordagens, métodos e historiografia da História da Ciência. In: MARTINS, A. M. (Org.). O tempo e o cotidiano na história. São Paulo: Fundação de Desenvolvimento da Educação, 1993. p. 73-78.

História e História da Ciência: Encontros e Desencontros. In: CONGRESSO LUSOBRASILEIRO DE HISTÓRIA DA CIÊNCIA E DA TÉCNICA, 1, 2001, Évora, Portugal. Actas... Universidade de Évora, 2001. p. 11- 45. Disponível em: <http://www.ifi.unicamp.br/ ghtc/ups/pub/246.PDF>. Acesso em: 12 jul. 2014.

Ciência versus historiografia: os diferentes níveis discursivos nas obras sobre história da ciência. In: ALFONSO-GOLDFARB, A. M.; BELTRAN, M. H. R. (Eds.). Escrevendo a História da Ciência: tendências, propostas e discussões historiográficas. São Paulo: EDUC/Livraria de Física, 2005. cap. 5, p. 115-145.

Introdução. A história das ciências e seus usos na educação. In: SILVA, C. C. (Org.). Estudos de história e filosofia das ciências: subsídios para aplicação no ensino. São Paulo: Livraria da Física, 2006. p. xxi-xxxiv.

MATTHEWS, M. R. Science teaching: the role of History and Philosophy of Science. New York, London: Routledge, 1994. 287 p. 
MCCOMAS, W. F.; AlMAZROA, H.; CLOUGH, M. The nature of science in science education: An introduction. Science \& Education, Dordrecht, v. 7, p. 511-532, 1998.

MCCOMAS, W. F. Seeking historical examples to illustrate key aspects of the nature of science. Science \& Education, Dordrecht, v. 17, p. 249-263, 2008.

OLIVEIRA, O. B. Em defesa da leitura de textos históricos na formação de professores de ciências. Pro-Posições, Campinas, v. 22, n. 1, p. 71-82, 2011.

OLIVEIRA, W. C. de. Ensinando sobre a Natureza da Ciência: uma abordagem explícita e contextualizada a partir da História do Vácuo. 2013. Dissertação (Mestrado) - UFRN. Disponível em: <http://repositorio.ufrn.br:8080/jspui/handle/123456789/16101>. Acesso em: 17 mai. 2015.

PAGLIARINI, C. R.; SILVA, C. C. A Estrutura dos Mitos Históricos nos Livros de Física. In: ENCONTRO DE PESQUISA EM ENSINO DE FÍSICA, 10, 2006, Londrina, PR. Disponível em: <http://www.ifsc.usp.br/ cibelle/arquivos/T0124-1.pdf>. Acesso em: 8 jul. 2014.

PEDUZZI, L. O. Q. Sobre a utilização didática da História da Ciência. In: PIETROCOLA, M. (Org.) Ensino de Física: conteúdo, metodologia e epistemologia numa concepção integradora. Florianópolis: Ed. da UFSC, 2001. cap. 7. p. 151-170.

PENA, F. L. A.; TEIXEIRA, E. S. Parâmetros para avaliar a produção literária em História e Filosofia da Ciência voltada para o ensino e divulgação das ideias da Física. Caderno Brasileiro de Ensino de Física, Florianópolis, v. 30, n. 3, p. 471-491, 2013.

PORTELA, S. I. C. O uso de casos históricos no Ensino de Física: Um exemplo em torno da temática do horror da natureza ao vácuo. 2006. Dissertação (Mestrado) UnB. Disponível em: $<$ http://bdtd.bce.unb.br/tedesimplificado/tde_busca/arquivo.php?codArquivo=1502>. Acesso em: 10 mai. 2015.

QUEIRÓS, W. P.; BATISTETI, C. B.; JUSTILA, L. A. D. Tendências das pesquisas em História e Filosofia da ciência e ensino de ciências: o que o ENPEC e o EPEF nos revelam? In: ENCONTRO NACIONAL DE PESQUISA EM EDUCAÇÃO EM CIÊNCIAS, 7, 2009, Florianópolis, SC. Disponível em: <http://posgrad.fae.ufmg.br/posgrad/viienpec/pdfs/1517.pdf>. Acesso em: 10 mai. 2015.

RIBEIRO, R. M. L.; MARTINS, I. O potencial das narrativas como recurso para o Ensino de Física: uma análise em livros didáticos de física. Ciência \& Educação, Bauru, v. 13, n. 3, p. 293-309, 2007. Disponível em: <http://www.scielo.br/scielo.php?script=sci_arttext\&pid=S1516-73132007000300002>. Acesso em: 17 mai. 2015.

SALTIEL, E.; VIENNOT, L. Qué aprendemos de las semejanzas entre las ideas historicas y el razonamiento espontáneo de los estudiantes? Enseñanza de las Ciencias, v. 3, n. 1, p. 137 - 
144, 1985. Disponível em: <http://www.raco.cat/index.php/Ensenanza/article/view/51883>. Acesso em: 4 mai. 2015.

SASSERON, L. H.; BRICCIA, V.; CARVALHO, A. M. P. de. Aspectos da natureza das Ciências em sala de aula: exemplos do uso de textos científicos em prol do processo de Alfabetização Científica dos estudantes. In: SILVA, C. C.; PRESTES, M. E. B. (Org.) Aprendendo ciência e sobre sua natureza: abordagens históricas e filosóficas. São Carlos: Tipographia, 2013. p. 265-276.

SCHMIEDECKE, W. G.; PORTO, P. A. Uma abordagem crítica para a história da ciência em programas de divulgação científica na televisão. In: ENCONTRO DE PESQUISA EM ENSINO DE FÍSICA, 9, 2013, Águas de Lindóia, SP. Disponível em: < http://www.nutes.ufrj.br/abrapec/ixenpec/atas/resumos/R0620-1.pdf>. Acesso em: 8 jul. 2014.

SILVEIRA, F. L. da. A Filosofia da Ciência e o Ensino de Ciências. Em Aberto, Brasília, v. 11, n. 55, p. 36-41, jul./set. 1992.

SOLAZ-PORTOLÈS, J. J. Concepciones de los estudiantes e Historia de la ciencia: el caso del concepto de vacío. [S. 1.: s. n.], 2008. Disponível em: <www.eumed.net/libros/2008c/451/>. Acesso em: 5 mai. 2015.

SOLAZ-PORTOLÈS, J. J.; MORENO-CABO, M. El espacio vacío y sus implicaciones en la historia de la ciencia. Caderno Brasileiro de Ensino de Física, Florianópolis, v. 14, n. 2, p. 194-208, ago. 1997. Disponível em: <https://periodicos.ufsc.br/index.php/fisica/article/viewFile/7033/6509>. Acesso em: 7 mai. 2015.

TEIXEIRA, E. S.; GRECA, I. M.; FREIRE JR, O. Uma revisão sistemática das pesquisas publicadas no Brasil sobre o uso didático de história e filosofia da ciência no ensino de física. In: PEDUZZI, L. O. Q.; MARTINS, A. F. P., FERREIRA, J. M. H. (Org.). Temas de história e filosofia da ciência no ensino. Natal: EDUFRN, 2012. cap. 1, p. 9-40. Disponível em: $<$ http://ppgect.ufsc.br/files/2012/11/Temas-de-Historia-e-Filosofia-da-Ciencia-no-Ensino1.pdf>. Acesso em: 17 mai. 2015.

VIDEIRA, A. A. P. Historiografia e história da ciência. Escritos (Fundação Casa de Rui Barbosa), Rio de Janeiro, v. 1, p. 111-158, 2007. Disponível em: <http://www.casaruibarbosa.gov.br/escritos/numero01/FCRB_Escritos_1_6_Antonio_Augusto_Passos_Videira.pdf>. Acesso em: 10 mai. 2015.

XAVIER, da S. E. O uso de fontes históricas como ferramentas na produção do conhecimento histórico: a canção como mediador. Antíteses, Londrina, v. 3, n. 6, p. 1097-1112, 2010. Disponível em: <http://www.uel.br/revistas/uel/index.php/antiteses/article/view/5062>. Acesso em: 17 mai. 2015. 


\title{
Apêndice 1 \\ Para Michelangelo Ricci em Roma
}

\begin{abstract}
Muito Ilustre Senhor e
Muito Erudito Patrono
\end{abstract}

Florença, 11 de Junho de 1644.

Muitas semanas atrás, eu enviei ao Senhor Antonio Nardi várias das minhas demonstrações a respeito das áreas de cicloides, e pedi-lhe que depois de examiná-las ele as enviasse imediatamente a você ou ao Senhor Magiotti. Eu já havia chamado a atenção para o fato de que estão sendo realizados certos experimentos filosóficos, não sei exatamente o que, relacionados ao vácuo, elaborados não simplesmente para produzir vácuo, mas para chegar a um instrumento que nos mostrará as mudanças na atmosfera, se está agora mais pesada e densa e depois mais leve e sutil. Muitos disseram que o vácuo não existe, outros que de fato existe apesar da repugnância da natureza e com dificuldade; eu não conheço alguém que tenha dito que exista sem dificuldade e sem uma resistência da natureza. Eu argumentei então: Se puder ser encontrada uma causa manifesta da qual a resistência, que é sentida se tentamos produzir vácuo, possa ser originada, parece-me tolice tentar atribuir ao vácuo aquelas operações que se seguem evidentemente de alguma outra causa; e, então, fazendo alguns cálculos muito simples, percebi que a causa identificada por mim (isto é, o peso da atmosfera) deveria por si só oferecer uma resistência maior do que o faz quando tentamos produzir um vácuo. Digo isso porque um certo filósofo, percebendo que não pode fugir da admissão de que o peso da atmosfera causa a resistência sentida ao se produzir o vácuo, não diz que admite a atuação do ar pesado, mas persiste afirmando que a natureza também colabora resistindo ao vácuo. Vivemos imersos no fundo de um oceano de ar elementar, o qual, por experimento, sem dúvida tem peso, e tanto peso que o ar mais denso na vizinhança da superfície da terra pesa cerca de uma quatro-centésima parte do peso da água. Determinados autores observaram depois do crepúsculo que o ar vaporoso e visível se eleva sobre nós a uma altura de cinquenta a cinquenta e quatro milhas, mas não acho que isso seja tanto, pois posso mostrar que o vácuo deveria oferecer uma resistência muito maior do que o faz; a menos que [isto é, para aceitar-se que a elevação seja de cerca de cinquenta milhas] usemos o argumento de que o peso que Galileo atribuiu se aplique à atmosfera mais baixa, onde os homens e os animais vivem, enquanto que nos picos das altas montanhas o ar começa a se tornar mais puro e a pesar muito menos do que a quatro-centésima parte do peso da água. Fizemos muitos recipientes de vidro como aqueles mostrados em A e B [Figura original] com tubos de dois cúbitos de comprimento. Estes foram preenchidos com mercúrio, suas extremidades fechadas com o dedo, e foram, então, invertidos em um recipiente $\mathrm{C}$ onde havia mercúrio;

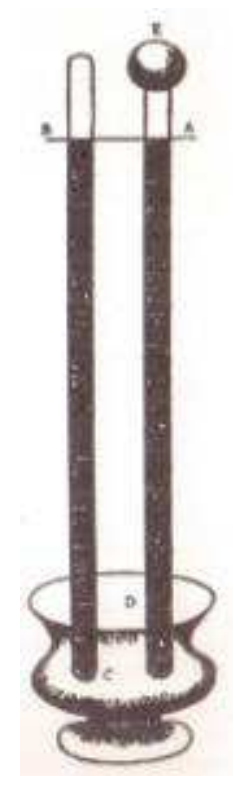


vimos que um espaço vazio foi formado e que nada aconteceu no tubo onde esse espaço foi formado; o tubo entre A e D permaneceu sempre cheio até a altura de um cúbito e um quarto e uma polegada. Para mostrar que o tubo estava completamente vazio, enchemos a bacia com água pura até D e então, erguendo o tubo pouco a pouco, vimos que, quando a abertura do tubo alcançou a água, o mercúrio caiu do tubo e a água subiu com grande violência até a marca $\mathrm{E}$. Costuma ser dito como explicação para o fato de que o tubo $\mathrm{AE}$ permanece vazio e o mercúrio, embora pesado, seja sustentado no tubo AC, que, como se acredita até agora, a força que impede que o mercúrio caia, como naturalmente o faria, é interna ao tubo $\mathrm{AE}$, e provém do vácuo ou de alguma substância extremamente rarefeita; mas afirmo que é externa, e que essa força vem de fora. Sobre a superfície do líquido que está na bacia repousa o peso de uma [coluna de] altura de cinquenta milhas de ar; então, e se no tubo CE, no qual o mercúrio não sofre tendência ou repugnância alguma, nem mesmo mínimas, a estar lá, devesse entrar e subir uma coluna alta o suficiente para entrar em equilíbrio com o peso do ar exterior que o força a subir? A água em um tubo similar, embora mais longo, subirá até cerca de 18 cúbitos, isto é, [sobe] tanto mais do que aquilo que o mercúrio sobe, o quanto ele é mais pesado do que a água; de forma a haver um equilíbrio com a mesma causa que atua sobre um e sobre o outro. Este argumento é reforçado por um experimento feito simultaneamente com o tubo A e com o tubo B, no qual o mercúrio sempre permanece na mesma linha horizontal $\mathrm{AB}$. Isso deixa quase que certo que a ação não se origina de dentro; porque o vaso $\mathrm{AE}$, onde haveria mais substância rarefeita, deveria ter exercido uma força maior, atraindo muito mais ativamente, por causa da maior rarefação, do que se observa no espaço menor B. Tenho me empenhado em explicar por esse princípio todos os tipos de repugnâncias que são sentidas em vários efeitos atribuídos ao vácuo, e ainda não encontrei alguma com a qual não consiga lidar com sucesso. Sei que o altíssimo senhor [dirigindo-se a Ricci] irá perceber muitas objeções, mas espero que se o senhor pensar sobre elas, as mesmas sejam resolvidas. Não fui capaz de concretizar minha intenção principal, isto é, reconhecer quando a atmosfera é mais densa e mais pesada e quando é mais sutil e mais leve, porque o nível $\mathrm{AB}$ no instrumento $\mathrm{EC}$ varia por alguma outra razão (o que eu não teria acreditado) especialmente como se fosse sensível ao frio ou ao calor, exatamente como se o tubo $\mathrm{AE}$ estivesse cheio de ar.

Seu servidor devotado e grato V. Torricelli 


\section{Apêndice 2}

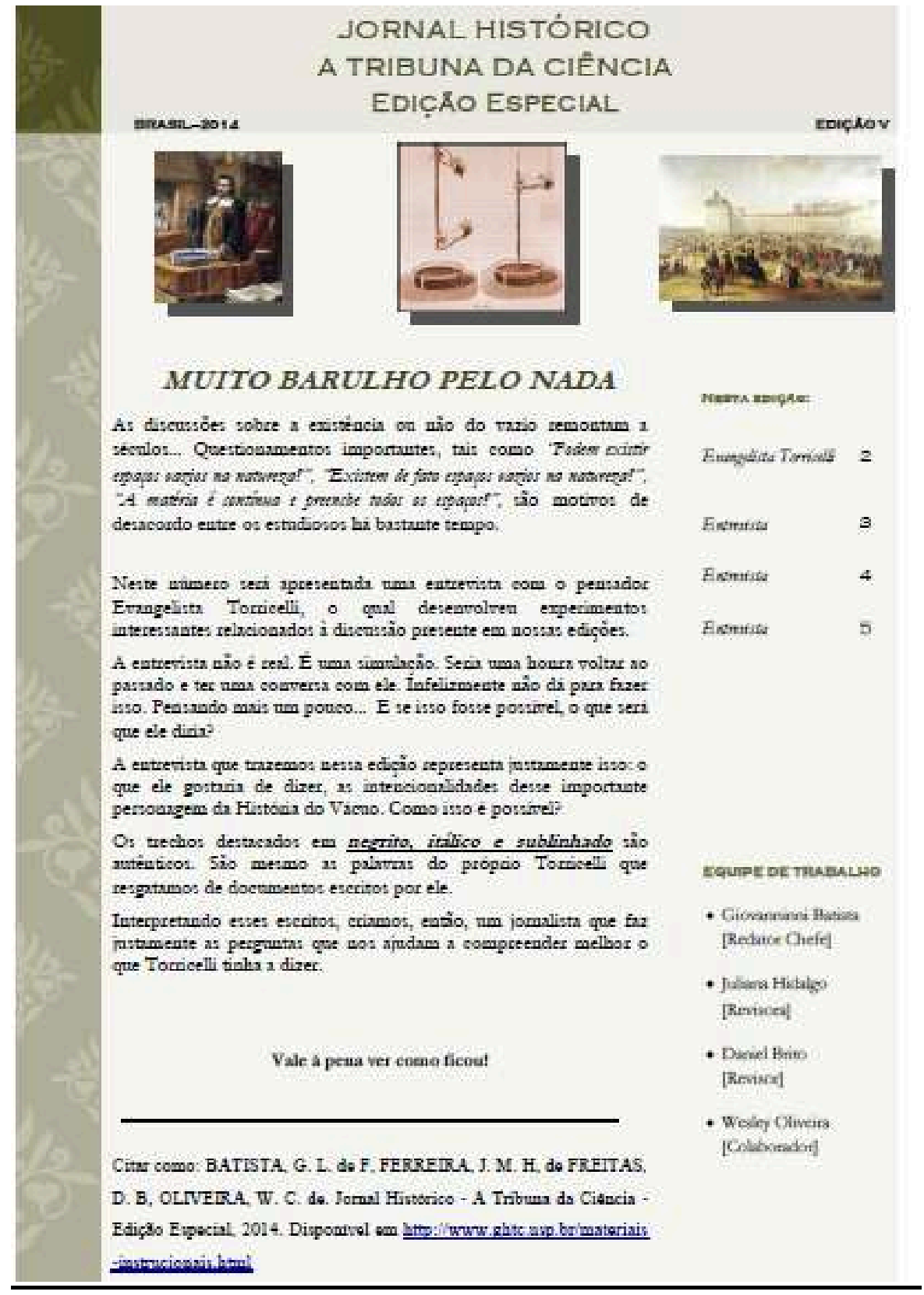


Jornalista: Então... Existe ○ vazio ou não?

Torricelli: Fizemos muitos recipientes de vidro como aqueles mostrados em $\mathrm{A}$ e B (fig. X) com tubos de dois cúbitos de comprimento. Estes foram preenchidos com mercúrio, suas extremidades fechadas com o dedo, e foram, então, invertidos em um recipiente $C$ onde havia mercúrio; vimos que um espaço vazio foi formado e que nada aconteceu no tubo onde esse espaço foi formado; o tubo entre $A$ \& $D$ permaneceu sempre cheio até a altura de um cúbito $e$ um quarto $e$ uma polegada. Para mostrar que o tubo estava completamente vazio, enchemos a bacia com água pura até $\mathrm{D}$ e então, erguendo o tubo pouco a pouco, vimos que, quando a abertura do tubo alcançou $a$ água, o mercúrio caiu do tubo e a água subiu com grande violência até

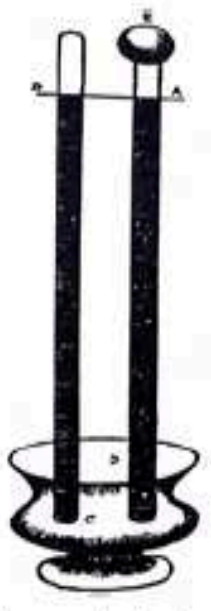

Representaçäo dos tubos utilizados pelo senhor Torricelli
Jornalista: Então o senhor está aceitando que o vácuo existe?

Torricelli: Muitos disseram que o vácuo não existe, outros que de fato existe apesar da repugnância da natureza e com dificuldade; eu não conheço alguém que tenha dito que exista sem dificuldade e sem uma resistência da natureza. Aceito a existência do vácuo, mas ele ocorre com alguma resistência na natureza.
Jornalista: Mas se o vácuo existe, ele não seria a causa da sustentação da coluna de mercúrio? Ele não daria um puxão, como dizem? Para o senhor, então, o que sustenta a coluna de mercúrio?

Torricelli: Costuma ser dito como explicação para of ato de que o tubo $A E$ permanece vazio e - mercúrio, embora pesado, seja sustentado no tubo AC, que, como se acredita até agora, a força que impede que o mercúrio caia, como naturalmente of faria, é interna ao tubo $A E$, e provém do vácuo ou de alguma substância extremamente rarefeita; mas afirmo que é externa, e que essa força vem de fora. 
Jornalista: Como assim? Que força seria essa?

Torricelli: Vivemos imersos no fundo de um oceano de ar elementar, o qual, por experimento, sem dúvida tem peso, e tanto peso que o ar mais denso na vizinhança da superfície da terra pesa cerca de uma quatro-centésima parte do peso da água. Esse peso, determinado por Galileu, podemos considerar que se aplique à atmosfera mais baixa, onde os homens $e$ os animais vivem, enquanto que nos picos das altas montanhas o ar começa a se tornar mais puro e a pesar muito menos do que a quatro-centésima parte do peso da água. No nosso caso, estamos realizando o experimento na superfície da terra.. Sobre a superfície do líquido que está na bacia repousa o peso de uma [coluna de] altura de cinquenta milhas de ar; então, e se no tubo $C E$, no qual o mercúrio não sofre tendência ou repugnância alguma, nem mesmo mínimas, a estar lá, devesse entrar e subir uma coluna alta o suficiente para entrar em equilibrio com o peso do ar exterior que of força a subir?

Jornalista: Mas mesmo considerando que o ar tem peso e atua sobre o mercúrio, ainda assim poderíamos considerar que aquele espaço vazio ou com alguma substância bem rarefeita tem alguma influência na altura da coluna de mercúrio?

Torricelli: A água em um tubo similar, embora mais longo, subirá até cerca de 18 cúbitos, isto $\dot{e}_{2}$ [sobe] tanto mais do que aquilo que o mercúrio sobe, o quanto ele é mais pesado do que a água; de forma a haver um equilibrio com a mesma causa que atua sobre um e sobre o outro. Este argumento $\dot{e}$ reforçado por um experimento feito simultaneamente com o tubo $A$ e com o tubo $B$, no qual o mercúrio sempre permanece na mesma linha horizontal $\mathrm{AB}$. Isso deixa quase que certo que a ação não se origina de dentro; por que o vaso $A E$, onde haveria mais substância rarefeita, deveria ter exercido uma força maior, atraindo muito mais ativamente, por causa da maior rarefação, do que se observa no espaço menor $B$. Tenho me empenhado em explicar por esse princípio todos os tipos de repugnâncias que são sentidas em vários efeitos atribuídos ao vácuo, $e$ ainda não encontrei alguma com a qual não consiga lidar com sucesso. [...] parece-me tolice tentar atribuir ao vácuo aquelas operações que se seguem evidentemente de alguma outra causa.

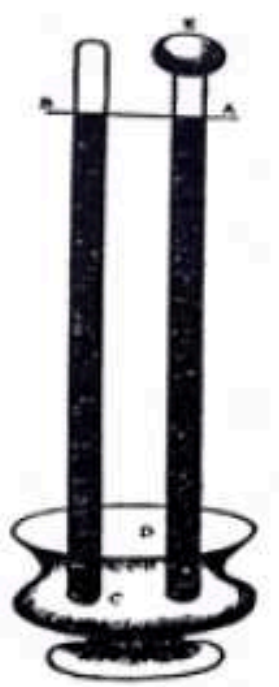

Representação dos tubos utilizados pelo senhor Torricelli 
Jornalista: Parece que o senhor realmente está interessado nesse assunto. Por quê?

Torricelli: Eu e vários senhores com os quais tenho me correspondido como os senhores Michelangelo Ricci, Antonio Nardi e Magiotti. Escrevi ao senhor Ricci relatando os resultados que agora the apresentei. Disse a ele: "irá perceber muitas objeções, mas espero que se o senhor pensar sobre elas, as mesmas sejam resolvidas". Eu já havia chamado a atenção para o fato de que estão sendo realizados certos experimentos filosóficos, não sei exatamente o que, relacionados ao vácuo, elaborados não simplesmente para produzir vácuo, mas para chegar a um instrumento que nos mostrará as mudanças na atmosfera, se está agora mais pesada e densa e depois mais leve $e$ sutil.

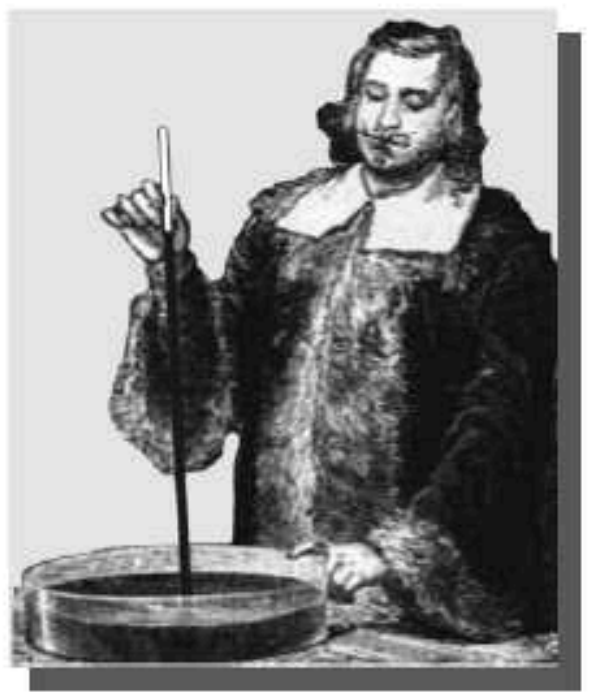

Jornalista: Estudar as mudanças na atmosfera... mas, isso seria ótimo! O senhor está encontrando alguma dificuldade na realização desse trabalho? Já tem resultados convincentes?

Torricelli: Exatamente. Minha intenção principal é reconhecer quando a atmosfera é mais densa e mais pesada e quando é mais sutil e mais leve. Mas ainda não fui capaz de concretizá-la porque o nível $A B$ no instrumento $E C$ varia por alguma outra razão, o que eu não teria acreditado, especialmente como se fosse sensível ao frio ou ao calor, exatamente como se o tubo AE estivesse cheio de ar.

Jornalista: Isso é estranho... O senhor não disse que o tubo estava vazio? Bem, não quero aborrecê-lo. Sabemos que essa é uma pergunta muito complicada. E que, por outro lado, é justamente a dúvida e não a certeza que estimula o pesquisador. Nossos leitores agradecem ao ilustre pesquisador e vamos continuar acompanhando de perto suas pesquisas! 


\section{Apêndice 3}

22 de setembro de 1648 .

[Após citar os nomes dos cavalheiros de Clermont que o acompanhavam, Périer inicia o relato dos experimentos.]

Encontramo-nos, então, naquele dia às oito horas da manhã no jardim dos Pères Minimes, o qual é praticamente a parte mais baixa da cidade, onde o experimento começou da seguinte maneira:

Primeiro, despejei em um vasilhame dezesseis libras de mercúrio, o qual eu havia purificado durante os três dias precedentes, e tomando dois tubos de vidro de tamanhos iguais, cada um com cerca de 4 pés de comprimento, hermeticamente selados em uma extremidade e aberto na outra, fiz com cada um o experimento comum do vácuo usando o mesmo vasilhame, e quanto aproximei os dois tubos sem retirá-los do vaso, verifiquei que o mercúrio que restou em cada um estava no mesmo nível, e que ficou em cada um deles acima do mercúrio no vasilhame vinte e seis polegadas e três linhas e meia. Repeti esse experimento duas vezes no mesmo local, com os mesmo tubos, com o mesmo mercúrio e no mesmo vasilhame; encontrei sempre o mercúrio nos tubos no mesmo nível e na mesma altura que encontrei na primeira vez.

Após isso ter sido realizado, deixei um dos dois tubos no vasilhame, para observação contínua: registrei no vidro a altura do mercúrio, e deixando o tubo nesse local, solicitei ao Reverendo Padre Chastin, um dos internos da casa, um homem tão piedoso quanto possível, e o qual reflete muito claramente em questões desse tipo, que tivesse o trabalho de observar a situação de tempo em tempo durante o dia, para verificar se qualquer mudança ocorria. E com o outro tubo e parte do mesmo mercúrio, eu subi com todos esses senhores ao topo do Puy-deDôme, que é cerca de quinhentas toesas mais alto que o Minimes, e quando realizamos os mesmos experimentos da mesma maneira que eu havia feito nos Minimes, encontrei que permaneceu no tubo não mais do que vinte e três polegadas e duas linhas de mercúrio, enquanto que no Minimes havia sido encontrada no mesmo tubo uma altura de vinte e seis polegadas, três linhas e meia; e então havia entre as alturas do mercúrio nos experimentos uma diferença de três polegadas e uma linha e meia: esse resultado nos encheu de admiração e espanto, e tanto nos surpreendeu, que para nossa própria satisfação desejamos repeti-lo. Por isso, repeti o mesmo mais cinco vezes, com grande precisão, em diferentes locais no topo da montanha, uma vez debaixo de uma cobertura numa pequena capela que existe lá, uma vez a céu aberto, uma vez em um abrigo, uma vez ao vento, uma vez com tempo bom, e uma vez sob chuva e névoa que nos atingiu algumas vezes, tendo o cuidado de retirar o ar do tubo todas as vezes; em todos esses testes encontrou-se a mesma altura para o mercúrio, vinte e três polegadas e duas linhas, o que corresponde a uma diferença de três polegadas e uma linha e meia das vinte e seis polegadas e três linhas e meia que foram encontradas no Minimes; esse resultado nos satisfez plenamente. 
[O restante da carta se refere a outros experimentos realizados durante a descida, e relata que a altura do mercúrio no tubo estacionário não mudou durante o dia. Também relata que a altura do mercúrio encontrada é levemente menor quando se ascende ao topo da Catedral em Clermont. O comunicado a seguir é o comentário de Pascal sobre esta carta.]

Esse relato esclareceu todas minhas dificuldades e não escondo o fato de que estou muito satisfeito com isso; e desde que percebi que a distância de vinte toesas na altura gerava uma diferença de duas linhas na altura do mercúrio, e que seis ou sete toesas gerava uma diferença de cerca de meia linha, um fato que é facilmente testado nessa cidade, eu fiz o experimento comum do vácuo no topo e na base da torre de Saint-Jacques de-la-Boucherie, a qual tem entre vinte e quatro e vinte e cinco toesas de altura: encontrei uma diferença de mais de duas linhas na altura do mercúrio; e, então, fiz o mesmo experimento em uma casa particular, com noventa e seis degraus de escada, onde encontrei muito claramente uma diferença de metade de uma linha; o que está perfeitamente de acordo com o relato de Périer. 